\title{
Fractionation of Rare Earth Elements in Greisen and Hydrothermal Veins Related to A-Type Magmatism
}

\author{
Mikael Tillberg $\mathbb{D}^{1},{ }^{1}$ Olga M. Maskenskaya, ${ }^{1}$ Henrik Drake $\mathbb{C}^{1},{ }^{1}$ Johan K. Hogmalm, \\ Curt Broman, ${ }^{3}$ Anthony E. Fallick, ${ }^{4}$ and Mats E. Åström ${ }^{1}$ \\ ${ }^{1}$ Linnaeus University, Department of Biology and Environmental Science, SE-39182 Kalmar, Sweden \\ ${ }^{2}$ University of Gothenburg, Department of Earth Sciences, SE-40530 Gothenburg, Sweden \\ ${ }^{3}$ Stockholm University, Department of Geological Sciences, 10691 Stockholm, Sweden \\ ${ }^{4}$ Scottish Universities Environmental Research Centre, G75 0QF Glasgow, UK \\ Correspondence should be addressed to Mikael Tillberg; mikael.tillberg@lnu.se and Henrik Drake; henrik.drake@lnu.se
}

Received 27 March 2019; Revised 27 June 2019; Accepted 7 July 2019; Published 22 August 2019

Academic Editor: Andrea Brogi

Copyright (C) 2019 Mikael Tillberg et al. This is an open access article distributed under the Creative Commons Attribution License, which permits unrestricted use, distribution, and reproduction in any medium, provided the original work is properly cited.

This study focuses on concentrations and fractionation of rare earth elements (REE) in a variety of minerals and bulk materials of hydrothermal greisen and vein mineralization in Paleoproterozoic monzodiorite to granodiorite related to the intrusion of Mesoproterozoic alkali- and fluorine-rich granite. The greisen consists of coarse-grained quartz, muscovite, and fluorite, whereas the veins mainly contain quartz, calcite, epidote, chlorite, and fluorite in order of abundance. A temporal and thus genetic link between the granite and the greisen/veins is established via high spatial resolution in situ Rb-Sr dating, supported by several other isotopic signatures $\left(\delta^{34} \mathrm{~S},{ }^{87} \mathrm{Sr} /{ }^{86} \mathrm{Sr}, \delta^{18} \mathrm{O}\right.$, and $\left.\delta^{13} \mathrm{C}\right)$. Fluid-inclusion microthermometry reveals that multiple pulses of moderately to highly saline aqueous to carbonic solutions caused greisenization and vein formation at temperatures above $200-250^{\circ} \mathrm{C}$ and up to $430^{\circ} \mathrm{C}$ at the early hydrothermal stage in the veins. Low calculated $\sum$ REE concentration for bulk vein $(15 \mathrm{ppm})$ compared to greisen $(75 \mathrm{ppm})$, country rocks $(173-224 \mathrm{ppm})$, and the intruding granite (320 ppm) points to overall low REE levels in the hydrothermal fluids emanating from the granite. This is explained by efficient REE retention in the granite via incorporation in accessory phosphates, zircon, and fluorite and unfavorable conditions for REE partitioning in fluids at the magmatic and early hydrothermal stages. A noteworthy feature is substantial heavy REE (HREE) enrichment of calcite in the vein system, in contrast to the relatively flat patterns of greisen calcite. The REE fractionation of the vein calcite is explained mainly by fractional crystallization, where the initially precipitated epidote in the veins preferentially incorporates most of the light REE (LREE) pool, leaving a residual fluid enriched in the HREE from which calcite precipitated. Fluorite occurs throughout the system and displays decreasing REE concentrations from granite towards greisen and veins and different fractionation patterns among all these three materials. Taken together, these features confirm efficient REE retention in the early stages of the system and minor control of the REE uptake by mineral-specific partitioning. REE-fractionation patterns and fluid-inclusion data suggest that chloride complexation dominated REE transport during greisenization, whereas carbonate complexation contributed to the HREE enrichment in vein calcite.

\section{Introduction}

The growing demand for rare earth elements (REE) in modern techniques for a sustainable environment has been associated with extensive prospecting for these metals worldwide [1]. Numerous laboratory experiments and genetic models have incorporated fluid-inclusion and isotopic data and/or trace element partitioning calculations to understand how
REE are transported, fractionated, and ultimately deposited in ores typically associated to the formation or alteration of carbonatitic and alkaline to peralkaline rocks [2-6]. REE enrichment in these systems is often ascribed to magmatic processes that can concentrate REE in fluoride liquids over silicate melt through liquid immiscibility [7] or in primary REE-rich minerals such as phosphates and zircon crystallizing from magma [8]. In late-magmatic stages, hydrothermal 
mobilization of REE transported via bonding with ligands such as $\mathrm{F}^{-}, \mathrm{CO}_{3}{ }^{2-}, \mathrm{Cl}^{-}$, or $\mathrm{OH}^{-}$can form secondary vein mineralizations from emanating fluids [9]. Fluid-rock interactions may affect REE distribution along the fluid pathway, where the availability of REE-complexing agents and the solubility of REE precipitation products will control REE fractionation through retention and precipitation [10]. REE fluorides, carbonates, and hydroxides are strong complexes that can under certain conditions become unstable and thus act as depositional complexes with limited capability to carry REE [5]. In contrast, REE-chloride complexation, although weaker, can in the absence of insoluble REE-chloride minerals enable extensive REE transportation in many hydrothermal systems [11]. The preferred complexation of LREE by chloride and fluoride and HREE by hydroxide and carbonate ligands experimentally established at low temperatures (generally below $100^{\circ} \mathrm{C}$ or even at ambient conditions) is not as straightforward at higher temperatures, where $\mathrm{pH}$ and redox conditions and coexisting species in the solution have stronger impacts on REE selectivity [5]. Experimental data of REE-carbonate and -hydroxide complexation at elevated temperatures is particularly scarce, although recent simulations predict abundant transportation of REE carbonates in solutions with high $\mathrm{CO}_{2}$ and low salinity [12]. Fluidrock and fluid-fluid interactions add further complexity to REE fractionation in natural systems, yet the applicability of experimentally determined partitioning has been implemented in geochemical, physical, and thermal evolution models of magmatic-hydrothermal systems at Strange Lake granitic pluton, Canada $[3,13]$ and in carbonatites such as those at Bayan Obo, China [14] and Songwe Hill, Malawi [15]. The large discrepancies in the distribution and fractionation of REE into minerals including calcite, fluorite, and apatite demonstrated in these studies appear to outline a virtually site-specific combination of transport and precipitation mechanisms affecting REE deposition. This complexity can be resolved by integrating the components involved at each stage throughout the evolution of the hydrothermal system [10]. We adopt this approach by scrutinizing fluidinclusion data along with REE abundance and patterns of whole-rock and mineral precipitates from the magmatic source rock and the host-rock reacting with the migrating fluids, as well as from the resulting greisen veins (hereafter named greisen) and distal veins (hereafter named veins) at a site on the Baltic Shield (Laxemar, SE Sweden). The overall aim is to assess mobilization, transportation, fractionation, and ultimate deposition of REE in the hydrothermal system. The temporal relationship between the intrusion and veins is investigated by a newly developed high spatial resolution $\mathrm{Rb}-\mathrm{Sr}$ dating technique [16], applied for the first time on hydrothermal veins and greisen mineralization.

\section{Geological Setting}

At the study site (Laxemar, SE Sweden), the country rock is part of the Transscandinavian Igneous Belt (TIB) and is composed of a suite of approximately $1.80 \mathrm{Ga}$ intrusive rocks dominated by granodiorite and quartz-monzodiorite with close temporal and genetic relationships (Figure 1).
The TIB formed during several pulses of magmatism between the Svecokarelian terraine to the north and the younger SW Scandinavian domain in the west [17]. Two alkali- and fluorine-rich granite plutons, the Götemar and Uthammar granites, crop out in the area (Figure 1). These are most likely syntectonic intrusions related to far-field effects of the 1.47 to $1.44 \mathrm{Ga}$ Danopolonian compressional event $[18,19]$, as shown by an overlapping U-Pb zircon age $(1433 \pm 10 \mathrm{Ma})$ for the Götemar granite [20]. They are laccolithshaped and have greater lateral extent in the subsurface than at the groundsurface, and are characterized by a narrowing root zone or feeder reaching a depth of approximately $4 \mathrm{~km}$ (Figure 1(c)) [21]. The Götemar granite is a horizontally zoned tabular structure with a diameter of $5 \mathrm{~km}$, formed at an estimated crustal depth of $4-8 \mathrm{~km}$ [22]. It is geochemically classified as a metaluminous to peraluminous anorogenic granite [23] with high $\mathrm{FeO} / \mathrm{MgO}$ and $\mathrm{Na}_{2} \mathrm{O}+\mathrm{K}_{2} \mathrm{O} / \mathrm{CaO}$ ratios. It is dominated by quartz and feldspars (up to $80 \mathrm{vol} . \%$, where the proportion of $\mathrm{K}$-feldspar: alkali plagioclase $\approx 1: 1$ ), and contains muscovite in minor amounts $(<5 \%)[24,25]$. Greisen mineralization constituting $\mathrm{cm}$-thick fluorite-rich quartzmuscovite veins was formed in the country rock at a late stage of the Götemar granite intrusion [26, 27].

Although no economic REE mineralizations occur in the area, a large number of vein generations have formed throughout the geological history of the TIB rocks. The oldest generation is related to the waning stages of the Svecokarelian orogeny (1750-1620 Ma) and the youngest to low-temperature conditions in the Quaternary [19, 28, 29]. Veins related to the granite plutons $(1433 \pm 10 \mathrm{Ma})$, in focus here, are identified by (i) the occurrence of epidote, (ii) nonbiogenic $\delta^{13} \mathrm{C}$ values of the calcite, that is, in the -7 to $-2 \%$ V-PDB range, (iii) relatively low $\delta^{18} \mathrm{O}(-25$ to $-10 \%$ o $\mathrm{V}-\mathrm{PDB})$ and ${ }^{87} \mathrm{Sr} /{ }^{86} \mathrm{Sr}$ values $(0.705-0.710)$ of the calcites [26], and (iv) hydrothermally red-stained wall rock [30] that has secondary mica ${ }^{40} \mathrm{Ar} /{ }^{39} \mathrm{Ar}$ ages overlapping with greisen mica and the granite [27]. Furthermore, several vein generations were formed during the Palaeozoic, and multiple episodes of ancient microbial activity in the bedrock fractures have been recorded from the Paleozoic to the Quaternary $[28,29,31]$. Although the general decrease in temperature over time has had a profound effect on the mineral assemblage of the veins, several minerals, such as calcite, have been formed under both high- and low-temperature conditions and thus exist in most generations [27]. This phenomenon and the spatial restriction of the borehole diameter (approximately $5 \mathrm{~cm}$ ) mean that it is not straightforward to assign a certain vein to a specific geological event.

\section{Materials and Methods}

3.1. Sampling. The Site Characterization Database (SICADA) owned by the Swedish Nuclear Fuel and Waste Management Co. (SKB) contains information on 50 cored boreholes with a total length of approximately $25 \mathrm{~km}$ in the Paleoproterozoic crystalline bedrock of the Laxemar area, SE Sweden. These boreholes, and the associated SICADA database, were made as part of previous, but now abandoned, investigations for a nuclear waste repository. This database was used 


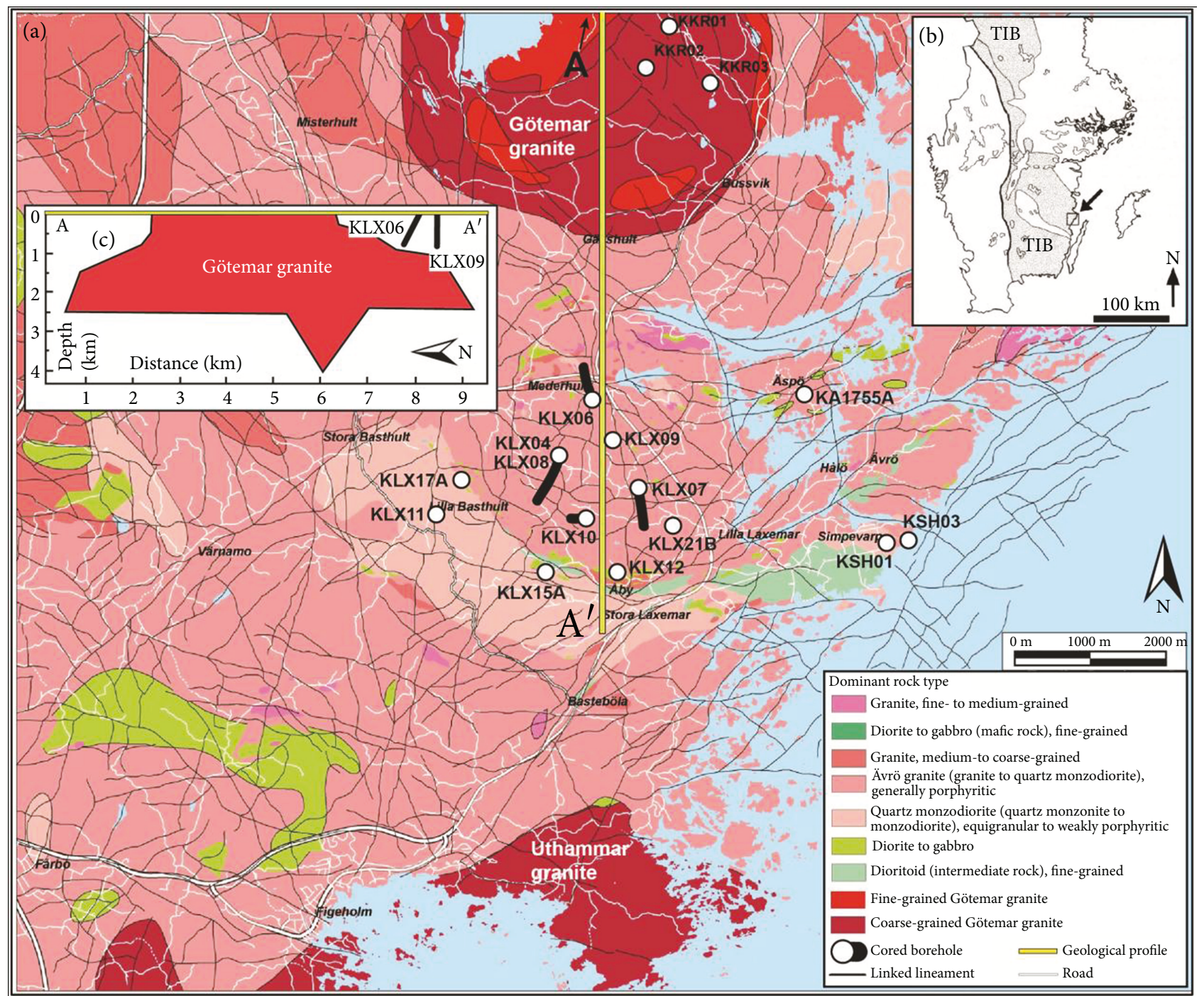

FIGURE 1: (a) Bedrock map after Wahlgren et al. [32] of the Laxemar area outlining borehole locations and fracture lineaments (also indicated are villages and roads). Thick black lines indicate underground extension of inclined drill cores. KLX04 is vertical while KLX08 stretches to SW. (b) Regional map of south Sweden indicating the location of the Transscandinavian Igneous Belt (TIB) in grey shade and the Laxemar area with arrow. (c) Geological model adapted from Cruden [21] of the Götemar granite across a N-S trending profile stretching beyond the map in a northerly direction, with the relative location of drill cores KLX06 and KLX09 indicated. At least one sample from each drill core outlined in the map has been used in this study.

for the identification of granite-associated veins in the Paleoproterozoic bedrock (TIB rocks). The diagnostic features included the presence of the index mineral epidote (Figures 2(a)-2(d) and 2(f)) ( \pm quartz, calcite, chlorite, and fluorite), the presence of alteration haloes (hydrothermally red-stained wall rock), and characteristic stable isotope ratios of calcite (existing information for a few veins) that distinguish them from abundantly occurring younger veins [26]. The relative proportions of the vein minerals were estimated based on macroscopic and microscopic observations, including photo documentation and available petrographic description of specimens being part of a previously published dataset $(n=26 ;[26])$. A compilation of samples and the analytical methods applied to each vein sample in this study is provided in Table 1 .
Greisen was, in a manner similar to the veins, identified in the SICADA database and sampled from the drill cores. Identification was based on its notable quartz-mica composition ( \pm fluorite, topaz, and sulphides; Figure 2(e)) and coarse-grained appearance (Figures 2(g) and 2(h)) and typical associated wall-rock sericitization-silicification with diffuse contact to the wall rock. Samples of quartzmonzodioritic to granodioritic rocks belonging to the TIB and coarse to medium-grained granite, fine-grained granite, and aplite dykes belonging to the Götemar granite were taken from fresh rock avoiding zones that were redstained or otherwise altered. A compilation of samples and the analytical methods applied to each greisen, Götemar granite, and TIB rock sample in this study is provided in Table 2. 


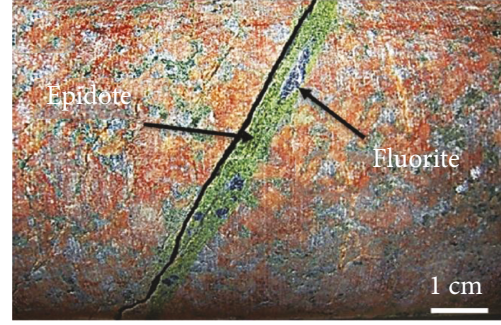

(a)

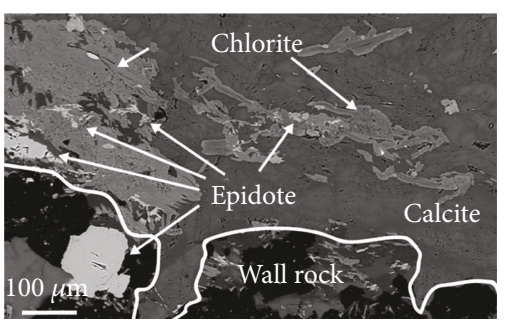

(b)

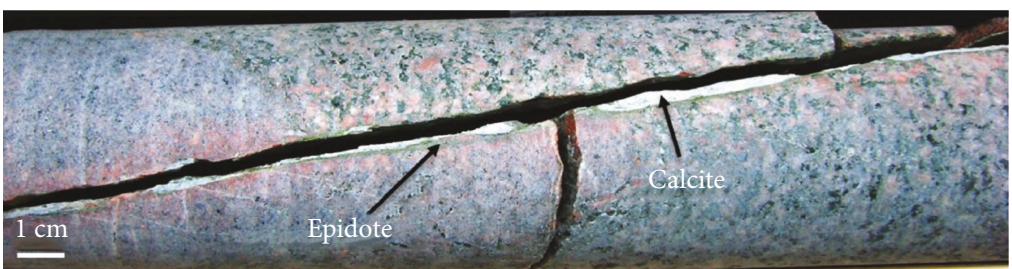

(c)

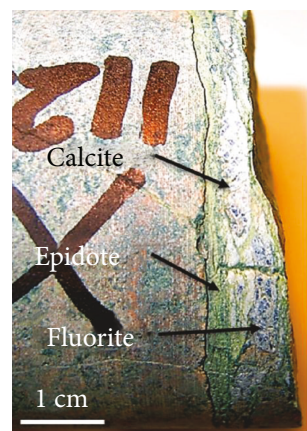

(d)

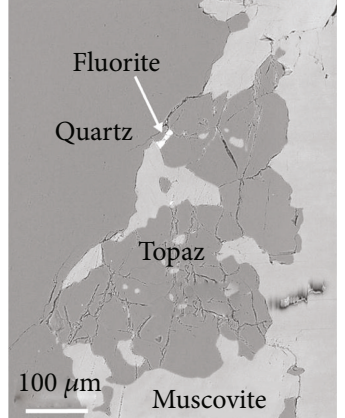

(e)

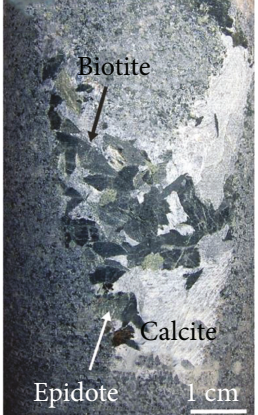

(f)

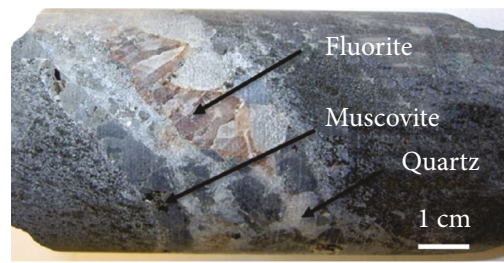

(g)

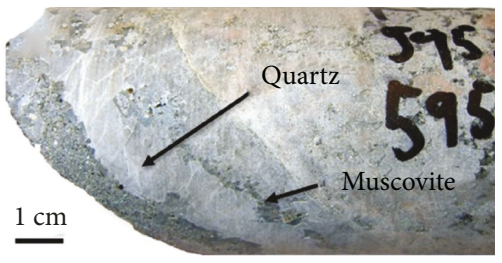

(h)

FIgURE 2: Representative vein (a-d) and greisen (e-h) specimens. (a) Photograph of sealed epidote-fluorite vein; (b) BSE image of epidote and chlorite lining a vein with calcite in the centre and in a veinlet penetrating into the wall rock; (c) photograph of a reactivated (presently open) vein with epidote closest to the wall rock and calcite precipitated after epidote; (d) photograph of a sealed epidote-calcite-fluorite vein; (e) BSE image of topaz intergrown with muscovite, fluorite, and quartz in greisen; (f) photograph of greisen containing epidote, biotite, and calcite; (g) photograph of fluorite-rich greisen with muscovite and quartz; (h) photograph of fluorite-poor greisen composed of quartz, muscovite, and low amounts of fluorite.

3.2. Chemical Analyses. Thick sections of veins, greisen, TIB rocks, and Götemar granite were polished and carbon coated, and the individual minerals were analysed by Scanning Electron Microscopy (SEM) and Energy Dispersive X-ray Spectroscopy (EDS) on a Hitachi S-3400N (Department of Earth Sciences, University of Gothenburg, Sweden; hereafter $\mathrm{GU})$ in order to verify pure mineral phases and obtain composition stoichiometry. The acceleration voltage was $20 \mathrm{kV}$, and specimen current was $1 \mathrm{nA}$. Oxide calibration standards were linked to a cobalt drift standard and a stable specimen current of $1 \mathrm{nA}$. X-ray spectrometric corrections were made by an INCA computer system. Spot size was $\sim 5 \mu \mathrm{m}$, and the detection limit was 0.1 oxide \%. After the SEM-EDS analyses, the identified minerals were analysed for major and trace elements by laser ablation inductively coupled plasma mass spectrometry (LA-ICP-MS) using either a LSX-200 Cetax or a NWR213 UV laser system followed by analyses on an Agilent 7500 or an Agilent 8800 . The LSX-200 laser was run with $4 \mathrm{~mJ}$ power at $4 \mathrm{~Hz}$ and a $200 \mu \mathrm{m}$ spot size. The raw counts were reduced using inhouse software (LaserCalc). NWR213 was run with 0.355 to $1.015 \mathrm{~mJ}$ power at $5-10 \mathrm{~Hz}$ and a $10-100 \mu \mathrm{m}$ spot size. Data processing was carried out using Glitter software. Calibration standard (NIST-612 glass), secondary standard of homogeneous greisen fluorite (only for fluorite), and internal standards $\left({ }^{44} \mathrm{Ca}\right.$ for calcite and fluorite and ${ }^{29} \mathrm{Si}$ for silicate 
TABLE 1: Summary of vein samples and analytical techniques applied on them.

\begin{tabular}{|c|c|c|c|c|c|c|c|c|c|c|}
\hline Sample type & $\begin{array}{c}\text { Borehole } \\
\text { ID } \\
\end{array}$ & $\begin{array}{c}\text { Borehole } \\
\text { depth }(\mathrm{m})\end{array}$ & $\begin{array}{c}\text { Fluid } \\
\text { incl. }\end{array}$ & $\begin{array}{c}\text { Rb-Sr dating } \\
\text { (LA) }\end{array}$ & $\begin{array}{c}\delta^{34} \mathrm{~S} \\
(\% \text { CDT }) \\
\end{array}$ & ${ }^{87} \mathrm{Sr} /{ }^{86} \mathrm{Sr}$ & $\begin{array}{l}\delta^{13} \mathrm{C} \\
(\% 0) \\
\end{array}$ & $\begin{array}{l}\delta^{18} \mathrm{O} \\
(\% 0)\end{array}$ & $\begin{array}{c}\text { Whole-rock } \\
\text { chemistry }\end{array}$ & $\begin{array}{c}\text { Mineral } \\
\text { chemistry }\end{array}$ \\
\hline Vein & KA1755A & 200 & & & & $\mathrm{cc}$ & $\mathrm{cc}$ & $\mathrm{cc}$ & & $\mathrm{LA} ; \mathrm{fl}(n=1)$ \\
\hline Vein & KA1755A & 204 & & & & & $\mathrm{cc}$ & $\mathrm{cc}$ & & \\
\hline Vein & KLX03 & 406 & $\mathrm{qz}$ & & & & & & & \\
\hline Vein & KLX03 & 416 & & & & & & & & ICP; $\mathrm{cc}(n=1)$ \\
\hline Vein & KLX03 & 722 & $\mathrm{qz}$ & & & & & & & ICP; $\mathrm{cc}(n=1)$ \\
\hline Vein & KLX03 & 733 & $\mathrm{qz}$ & & & & & & & $\mathrm{ICP} ; \mathrm{cc}(n=1)$ \\
\hline Vein & KLX04 & 119 & & & & $\mathrm{fl}$ & & & & \\
\hline Vein & KLX08 & 693 & & & & & & & & ICP; fl $(n=1)$ \\
\hline Vein & KLX09 & 207 & & & & & & & & $\begin{array}{l}\text { LA; fl }(n=1) \\
\text { ICP; fl }(n=1)\end{array}$ \\
\hline Vein & KLX09 & 693 & & & & & & & & $\mathrm{LA} ; \mathrm{fl}(n=1)$ \\
\hline Vein & KLX10 & 406 & & $\begin{array}{l}\text { bt }(n=8), \\
\text { cc }(n=7), \\
\text { ep }(n=2)\end{array}$ & & & & & & ICP; $\mathrm{cc}(n=1)$ \\
\hline Vein & KLX10 & 519 & & & & & & & & LA; epi $(n=8)$ \\
\hline Vein & KLX10 & 790 & & & & & $\mathrm{cc}$ & $\mathrm{cc}$ & & $\mathrm{ICP} ; \mathrm{cc}(n=1)$ \\
\hline Vein & KLX10 & 895 & & $\begin{array}{l}\text { bt }(n=7), \\
\text { cc }(n=2)\end{array}$ & & & & & & \\
\hline Vein & KLX10C & 225 & & & & & & & & $\mathrm{LA} ; \mathrm{fl}(n=1)$ \\
\hline Vein & KLX11 & 789 & & & & & & & & ICP; $\mathrm{cc}(n=1)$ \\
\hline Vein & KLX12 & 476 & $\mathrm{qz}$ & & py & & $\mathrm{cc}$ & $\mathrm{CC}$ & & $\begin{array}{l}\text { LA; epi }(n=1) \\
\text { ICP; } \operatorname{cc}(n=1)\end{array}$ \\
\hline Vein & KLX15A & 262 & & & & & $\mathrm{cc}$ & $\mathrm{cc}$ & & ICP; $\mathrm{cc}(n=1)$ \\
\hline Vein & KLX15A & 263 & & & & & $\mathrm{cc}$ & $\mathrm{cc}$ & & ICP; $\mathrm{cc}(n=1)$ \\
\hline Vein & KLX15A & 380 & & & & & $\mathrm{cc}$ & $\mathrm{cc}$ & & $\mathrm{LA} ; \operatorname{chl}(n=1)$ \\
\hline Vein & KLX15A & 381 & & & & & $\mathrm{Cc}$ & $\mathrm{CC}$ & & $\mathrm{LA} ; \operatorname{chl}(n=1)$ \\
\hline Vein & KLX17A & 199 & $\mathrm{qz}$ & & & & $\mathrm{cc}$ & $\mathrm{CC}$ & & ICP; $\mathrm{cc}(n=1)$ \\
\hline Vein & KLX21B & 596.4 & & & & & & & & $\mathrm{LA} ; \mathrm{fl}(n=1)$ \\
\hline Vein & KLX21B & 597.0 & & & & & $\mathrm{Cc}$ & $\mathrm{Cc}$ & & $\begin{array}{l}\text { LA; fl }(n=1) \\
\quad \text { epi }(n=1)\end{array}$ \\
\hline Vein & KLX21B & 597.4 & & & & & & & & $\mathrm{LA} ; \mathrm{fl}(n=1)$ \\
\hline Vein & KLX21B & 597.9 & & & & & & & & LA; fl $(n=1)$ \\
\hline Vein & KLX21B & 604 & & & & & & & & $\mathrm{LA} ; \mathrm{fl}(n=1)$ \\
\hline Vein & KSH01 & 376 & & & & & & & & ICP; $\mathrm{cc}(n=1)$ \\
\hline Vein & KSH01 & 401 & & & & & & & & ICP; $\mathrm{cc}(n=1)$ \\
\hline Vein & KSH01 & 875 & & & py & & & & & ICP; $\mathrm{cc}(n=1)$ \\
\hline Vein & KSH01A & 130 & & & & & $\mathrm{cc}$ & $\mathrm{cc}$ & & ICP; $\mathrm{cc}(n=1)$ \\
\hline
\end{tabular}

$\mathrm{bt}=$ biotite, $\mathrm{cc}=$ calcite, $\mathrm{chl}=$ chlorite, epi=epidote, $\mathrm{fl}=$ fluorite, $\mathrm{qz}=$ quartz, and $\mathrm{py}=$ pyrite. $\mathrm{ICP}=$ inductively coupled plasma mass spectrometer. $\mathrm{LA}=$ laser ablation inductively coupled plasma mass spectrometer.

minerals, where mineral-specific compositions were determined by SEM-EDS of the same crystals) were used for both laser runs. Accuracy was controlled by analyses of basalt glass standard (JB-1 and BCR-2G) and was generally better than $10 \%$.

Handpicked specimens of calcite and fluorite (cleaned by removing other minerals attached to the grains) of veins and greisen were analysed for $\mathrm{Mg}, \mathrm{Ca}, \mathrm{Mn}, \mathrm{Fe}, \mathrm{Rb}, \mathrm{Sr}, \mathrm{Y}$, and La-Lu by inductively coupled plasma (ICP) mass spectrometry (MS) on an Agilent 7500 ICP-MS at GU. $12 \mathrm{mg}$ of each calcite specimen was dissolved in $47 \mathrm{ml} 5 \% \mathrm{HNO}_{3}$ for $1 \mathrm{~h}$, whereas $50-100 \mathrm{mg}$ of fluorite was dissolved in a mixture of $3 \mathrm{ml} \mathrm{HNO}_{3 \text { (conc.) }}$ and $9 \mathrm{ml} \mathrm{HCl}_{\text {(conc.) }}$ overnight at $90^{\circ} \mathrm{C}$. The dried residue was treated with a mixture of $7.5 \mathrm{ml}$ $\mathrm{HNO}_{3 \text { (conc.) }}$ and $5 \mathrm{ml} \mathrm{H} \mathrm{H}_{2} \mathrm{O}$ overnight at $90^{\circ} \mathrm{C}$. Standards of dolomite (JDo-1), granite (SARM 48), and basalt (W-1) were included. Multielement standard solutions (Merck, VI CertiPUR, and Agilent diluted to 0.1, 1, 10, and $100 \mathrm{ppb}$ ) were used to construct linear calibration graphs. A solution containing equal amounts ( $800 \mathrm{ppb}$ ) of In and Re was used as an internal standard. Precision was generally better than $5 \%$, and accuracy was better than $10 \%$. 
TABLE 2: Summary of rock samples and analytical techniques applied on them.

\begin{tabular}{|c|c|c|c|c|c|c|c|c|c|c|}
\hline $\begin{array}{l}\text { Sample } \\
\text { type }\end{array}$ & $\begin{array}{c}\text { Borehole } \\
\text { ID/location }\end{array}$ & $\begin{array}{l}\text { Borehole } \\
\text { depth }(\mathrm{m})\end{array}$ & $\begin{array}{l}\text { Fluid } \\
\text { incl. }\end{array}$ & $\begin{array}{c}\text { Rb-Sr dating } \\
\text { (LA) }\end{array}$ & $\begin{array}{c}\delta^{34} \mathrm{~S} \\
(\% \circ \mathrm{CDT}) \\
\end{array}$ & ${ }^{87} \mathrm{Sr} /{ }^{86} \mathrm{Sr}$ & $\begin{array}{l}\delta^{13} \mathrm{C} \\
(\%)\end{array}$ & $\begin{array}{l}\delta^{18} \mathrm{O} \\
(\% \circ) \\
\end{array}$ & $\begin{array}{l}\text { Whole-rock } \\
\text { chemistry }\end{array}$ & $\begin{array}{c}\text { Mineral } \\
\text { chemistry }\end{array}$ \\
\hline TIB & KLX03 & 518 & & & & & & & & $\mathrm{LA} ; \operatorname{ttn}(n=2)$ \\
\hline TIB & KLX08 & $263(\mathrm{vd})$ & & & & & & & & $\mathrm{LA} ; \operatorname{ttn}(n=3)$ \\
\hline TIB & KSH01 & 3.7 & & & & & & & & $\begin{array}{c}\text { LA; chl }(n=4), \\
\text { plag }(n=6), \\
\text { hbl }(n=4), \\
\text { ap }(n=5), \\
\text { px }(n=4), \\
\text { ttn }(n=3), \\
\text { zrc }(n=3), \\
\text { bt }(n=2)\end{array}$ \\
\hline Granite & KKR01 & 153 & & & & & & & $\operatorname{ICP}(n=1)$ & \\
\hline Granite & KKR01 & 157 & & & & & & & $\mathrm{ICP}(n=1)$ & $\mathrm{LA} ; \mathrm{fl}(n=4)$ \\
\hline Granite & KKR01/03 & $492 / 498$ (vd) & & & & & & & & $\begin{array}{c}\mathrm{LA} ; \mathrm{ms}(n=1), \\
\operatorname{ap}(n=3), \\
\operatorname{zrc}(n=1)\end{array}$ \\
\hline Granite & KKR02 & 23 & & & & & & & $\mathrm{ICP}(n=1)$ & \\
\hline Granite & KKR02 & 213 & & & & & & & $\mathrm{ICP}(n=1)$ & $\mathrm{LA} ; \mathrm{mnz}(n=4)$ \\
\hline Granite & KKR03 & 258 & & & & & & & & $\begin{array}{c}\mathrm{LA} ; \mathrm{fl}(n=10) \\
\operatorname{mnz}(n=3)\end{array}$ \\
\hline Granite & KKR03 & 459 & & & & & & & $\operatorname{ICP}(n=1)$ & $\begin{array}{c}\mathrm{LA} ; \mathrm{fl}(n=3) \\
\operatorname{mnz}(n=3)\end{array}$ \\
\hline Granite & KKR03 & 539 & & & & & & & $\mathrm{ICP}(n=1)$ & LA; fl $(n=11)$ \\
\hline Granite & KKR03 & 643 & & & & & & & $\mathrm{ICP}(n=1)$ & \\
\hline Granite & Kråkemåla & Surface & & & & & & & & $\begin{array}{c}\text { LA; } \mathrm{ms}(n=4), \\
\mathrm{kf}(n=7), \\
\text { ap }(n=3)\end{array}$ \\
\hline Greisen & KLX06 & 535 & & & & & & & $\mathrm{ICP}(n=1)$ & ICP; fl $(n=1)$ \\
\hline Greisen & KLX06 & 543 & & & & & & & & $\mathrm{LA} ; \mathrm{ms}(n=1)$ \\
\hline Greisen & KLX06 & 565 & & $\begin{array}{l}\mathrm{ms}(n=6), \\
\mathrm{cc}(n=3), \\
\mathrm{fl}(n=3)\end{array}$ & & & & & $\mathrm{ICP}(n=2)$ & $\begin{array}{l}\text { ICP; fl }(n=1) \\
\text { LA; fl }(n=14), \\
\text { ms }(n=1)\end{array}$ \\
\hline Greisen & KLX06 & 572 & & $\begin{array}{c}\mathrm{ms}(n=8) \\
\mathrm{fl}(n=3)\end{array}$ & & & & & $\mathrm{ICP}(n=1)$ & $\mathrm{ICP} ; \mathrm{fl}(n=1)$ \\
\hline Greisen & KLX06 & 577 & & & & & & & & $\begin{array}{c}\text { LA; cc }(n=5), \\
\text { chl }(n=2), \\
\text { ms }(n=1)\end{array}$ \\
\hline Greisen & KLX06 & 590 & & & py & & & & & ICP; fl $(n=1)$ \\
\hline Greisen & KLX06 & 593 & & $\begin{array}{l}\text { bt }(n=2), \\
\text { kf }(n=2), \\
\text { cc }(n=1), \\
\text { fl }(n=1)\end{array}$ & & $\mathrm{fl}$ & & & & $\begin{array}{c}\text { LA; fl }(n=8), \\
\text { cc }(n=6), \\
\text { epi }(n=6), \\
\text { kf }(n=2)\end{array}$ \\
\hline Greisen & KLX06 & 595 & $\mathrm{qz}$ & & & & & & $\mathrm{ICP}(n=1)$ & $\begin{array}{c}\text { LA; } \operatorname{ms}(n=1), \\
\quad \operatorname{tpz}(n=6)\end{array}$ \\
\hline Greisen & KLX07 & 697 & & & & 11 & & & & \\
\hline
\end{tabular}

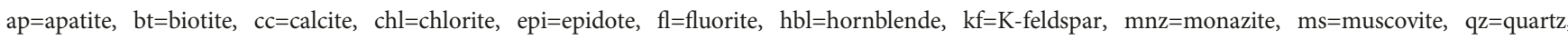
plag=plagioclase, $\mathrm{px}=$ pyroxene, $\mathrm{py}=\mathrm{pyrite}, \mathrm{tpz}=\mathrm{topaz}, \mathrm{ttn}=\mathrm{titanite}$, and $\mathrm{zrc}=\mathrm{zircon} . \mathrm{ICP}=$ inductively coupled plasma mass spectrometer. $\mathrm{LA}=\mathrm{laser}$ ablation inductively coupled plasma mass spectrometer. vd=vertical depth.

Bulk specimens of greisen $(n=5)$ and Götemar granite ( $n=4$ coarse/medium grained, $n=3$ fine grained, $n=4$ aplite) were analysed for concentrations of major elements
Sr and REE using ICP Atomic Emission Spectrometry (AES) and ICP Quadrupole Mass Spectrometry (QMS) at ALS Scandinavia AB, Luleå, Sweden. The analyses were made 
according to EPA-approved procedures documented in EPA methods 200.7 (for ICP-AES) and EPA methods 200.8 (for ICP-QMS). Each granite and greisen specimen was ground, fused with $\mathrm{LiBO}_{2}$, and finally dissolved in 5\% $\mathrm{HNO}_{3}$ prior to determination. The accuracy for all metals was generally better than $10 \%$.

3.3. Isotope Analyses. Isotope ratios of carbon $\left({ }^{13} \mathrm{C} /{ }^{12} \mathrm{C}\right)$ and oxygen $\left({ }^{18} \mathrm{O} /{ }^{16} \mathrm{O}\right)$ for 11 handpicked calcite vein specimens were determined at the Scottish Universities Environmental Research Centre (SUERC). Analysis of 1-2 mg calcite was performed on $\mathrm{CO}_{2}$ released by the phosphoric acid dissolution method [33] in an automated preparation system that includes cryogenic purification of the gas. The pure gas was introduced into a dual-inlet, triple-collector gas source isotope ratio mass spectrometer (Micromass SIRA 10). Calibration of the mass spectrometer standard gas was via NBS 19. Precision was $\pm 0.1 \%$ at $1 \sigma$. Oxygen isotope ratios were derived from the $\mathrm{CO}_{2}$-measured values using a phosphoric acid fractionation factor derived from the literature [34]. The results for carbon and oxygen isotopes are reported as \%o relative to $\mathrm{V}-\mathrm{PDB}$.

Sulphur isotope analyses of two handpicked pyrite vein specimens were carried out at the Swedish Museum of Natural History, Stockholm. $\mathrm{SO}_{2}$ was released from each pyrite specimen $(0.1-20 \mathrm{mg})$ following a method described elsewhere [35], whereby samples were combusted at $1070^{\circ} \mathrm{C}$ for $25 \mathrm{~min}$ in the presence of excess $\mathrm{Cr}_{2} \mathrm{O}_{3} \cdot \mathrm{SO}_{2}$ was separated from excess oxygen and other combustion products by standard vacuum line techniques, and the purified gas was analysed for ${ }^{34} \mathrm{~S} /{ }^{32} \mathrm{~S}$ on an isotope ratio mass spectrometer (Finnigan MAT DELTA Plus). Results are reported as \%o relative to VCDT. Reproducibility was better than $\pm 0.2 \%$ at $1 \sigma$.

Strontium isotope analyses on three handpicked fluorite specimens were carried out at the Institute of Energy Technology, Norway by thermal ionization mass spectrometry (Finnigan MAT 261). Each ground fluorite specimen was reacted with $1-2 \mathrm{M} \mathrm{HNO}_{3}$ at $50^{\circ} \mathrm{C}$ for 48 hours. The acquired solution was centrifuged, separated from the residue, evaporated, dissolved in $200 \mu \mathrm{l} 3 \mathrm{M} \mathrm{HNO}_{3}$, and then loaded onto an ion-exchange column packed with Sr-spec Eichrom resin. Unwanted elements were washed out with $3 \mathrm{M} \mathrm{HNO}_{3}$, and $\mathrm{Sr}$ was eluted with water. The eluate was evaporated and loaded on degassed Re filaments. Calibration was preformed via NIST/NBS 987 standards. Precision was $\pm 20 \mathrm{ppm}$. The total blank of Sr was 50-100 pg.

3.4. Fluid Inclusions. Quartz in one greisen and five vein samples were prepared as doubly polished, $150 \mu \mathrm{m}$ thick, fluid-inclusion wafers. Microthermometric analyses were undertaken at the Department of Geological Sciences, Stockholm University on a Linkam THMS600 heatingfreezing stage mounted on a Nikon microscope. The precision of the measurements was $\pm 0.1^{\circ} \mathrm{C}$ for temperatures below $+40^{\circ} \mathrm{C}$ and $\pm 0.5^{\circ} \mathrm{C}$ above $+40^{\circ} \mathrm{C}$. Solid phases or gaseous fluid components are identified by using a Horiba Jobin-Yvon LabRAM 800 HR Raman spectrometer and an Olympus BX41 petrographic microscope. The analyses were made using $514 \mathrm{~nm}$ excitation of an Ar-ion laser adjusted to an on-sample intensity of $5 \mathrm{~mW}$, with a laser beam focused to a spot of $1 \mu \mathrm{m}$. Raman acquisition was performed with a spectral range of $150-4200 \mathrm{~cm}^{-1}$ and a spectral resolution of about $0.3 \mathrm{~cm}^{-1}$, using a $1800 \mathrm{l} / \mathrm{mm}$ grating and an air-cooled $\left(-70^{\circ} \mathrm{C}\right) \mathrm{CCD}$ array detector.

3.5. In Situ Rb-Sr Dating. Three samples of $\mathrm{cm}$-thick greisen consisting of coarse-grained (up to $1.5 \mathrm{~cm}$ in diameter) muscovite, biotite, K-feldspar, quartz, and fluorite along with accessory calcite, chlorite, pyrite, and topaz and two samples of $2-3 \mathrm{~cm}$ thick veins comprising up to $0.5 \mathrm{~cm}$ sized biotite+ calcite \pm epidote were dated by in situ Rb-Sr LA-ICP-MS analysis. Isochrons were achieved by combining muscovite or biotite with $\mathrm{K}$-feldspar, calcite, fluorite, and/or epidote. $\mathrm{Rb}-\mathrm{Sr}$ analyses were performed at the microgeochemistry lab at GU using an ESI 213NWR laser ablation system connected to an Agilent 8800QQQ ICP-MS with an ORS3 (octopole reaction system) reaction cell installed between two quadropoles. Following laser warm-up, ablation occurred with a static spot mode in a constant He flow $(800 \mathrm{ml} / \mathrm{min})$. The ablated material was mixed with $\mathrm{N}_{2}$ and Ar before entering the ICP-MS torch region, where it reacted with $\mathrm{N}_{2} \mathrm{O}$ or $\mathrm{O}_{2}$ gas in the reaction cell. This reaction chemically separated ${ }^{87} \mathrm{Rb}$ from ${ }^{87} \mathrm{Sr}$ and thereby enabled calculation of ${ }^{87} \mathrm{Rb} /{ }^{86} \mathrm{Sr}$ and ${ }^{87} \mathrm{Sr} /{ }^{86} \mathrm{Sr}$ ratios. $\mathrm{N}_{2} \mathrm{O}, \mathrm{SF}_{6}[36]$, or $\mathrm{O}_{2}$ [16] were utilized as reaction gas in separate sessions. The raw ${ }^{87} \mathrm{Rb} /{ }^{86} \mathrm{Sr}$ and ${ }^{87} \mathrm{Sr} /{ }^{86} \mathrm{Sr}$ ratios were converted by correction factors derived from repeated analysis of standards NIST SRM 610 and mica-Mg-A1. ${ }^{87} \mathrm{Rb} /{ }^{86} \mathrm{Sr}$ normalization was performed by using mica-Mg, a reference mineral powder of a phlogopite separated from Bekily, Madagascar [37], pressed to a nanopellet tablet [36]. Sample data reduction and within-run error calculation of selected element and isotopic ratios were performed using an in-house spreadsheet. No error propagation from uncertainties of literature data or within-run errors of standards was applied to sample errors.

\section{Results}

4.1. Mineralogy and Chemistry of Bedrock. The TIB granitoid rocks comprise quartz and feldspars (up to 60-65 vol.\% proportion of K-feldspar:plagioclase $\approx 1: 3)$ with varying amounts of chlorite, biotite, pyroxene, amphibole, and accessory titanite, apatite, and magnetite. The total REE concentrations in these rocks are on average $173 \mathrm{ppm}$, with a strong enrichment of LREE relative to chondrite (Figure 3(d)). The eight minerals analysed for chemical elements show a large variability both in terms of REE concentrations and fractionation patterns as well as $\mathrm{Eu}$ anomalies (Figures 4(c)-4(f)), with the highest concentrations in titanite (mean $\sum \mathrm{REE}=18114 \mathrm{ppm}$ ) and apatite (mean $\left.\sum \mathrm{REE}=6307 \mathrm{ppm}\right)$. The concentrations of the other metals are given for all bulk rocks in Appendix A and for the individual minerals in Appendix B.

The Götemar granite contains rock-forming quartz, $\mathrm{K}$-feldspar, and plagioclase and accessory muscovite, fluorite, monazite, zircon, apatite, and rutile. In this rock, the REE occur in concentrations (mean $\sum \mathrm{REE}=320$ ) that are higher than in the TIB rocks. The coarse-grained granite variety 
Coarse-grained granite

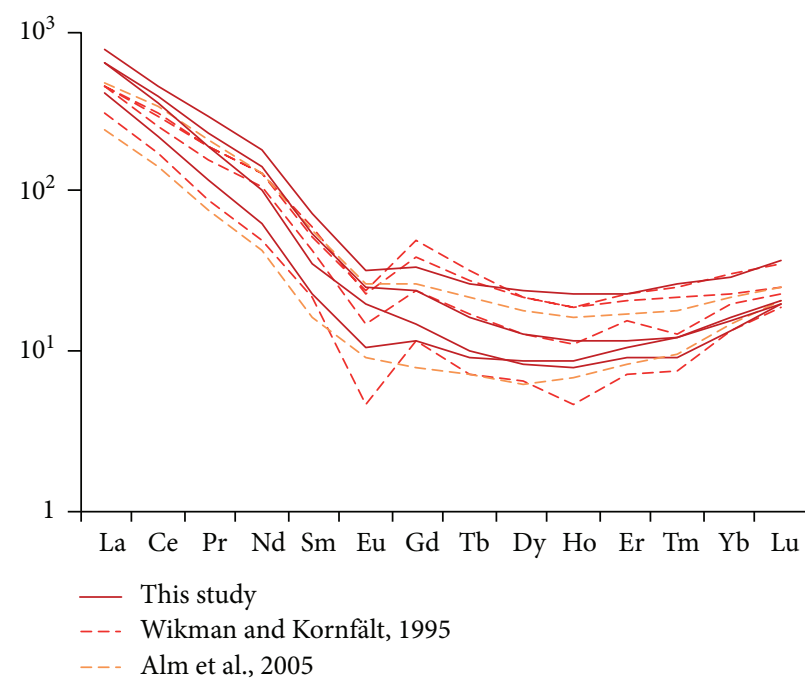

(a)

Bulk greisen and veins

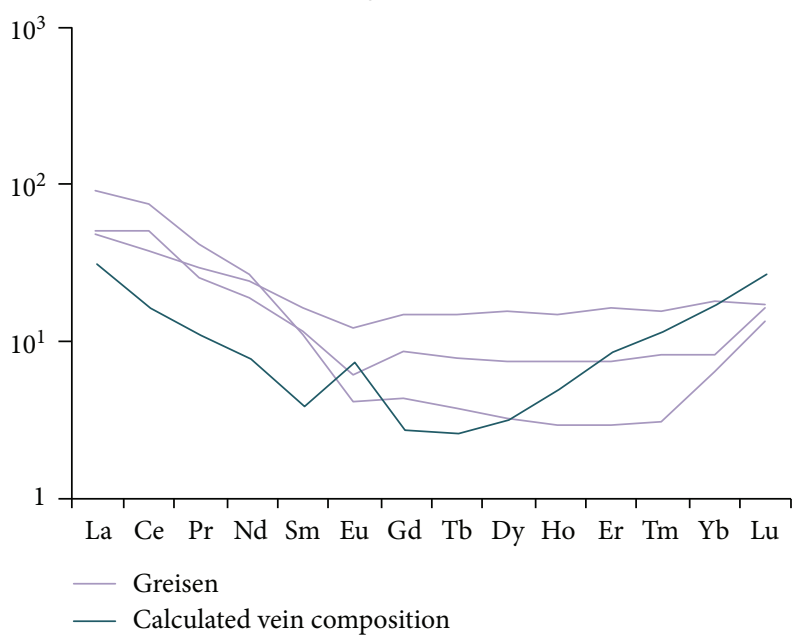

(c)
Fine-grained granite

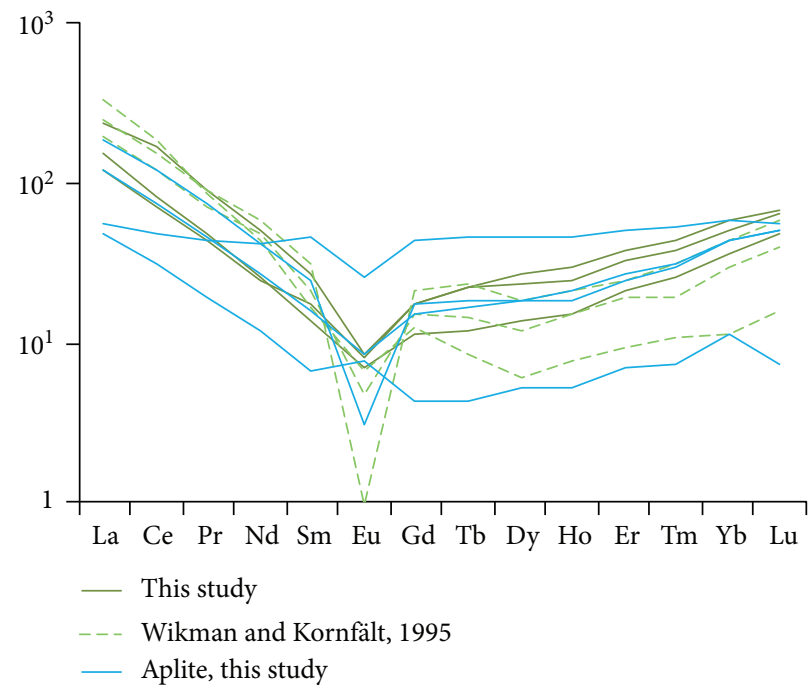

(b)

TIB

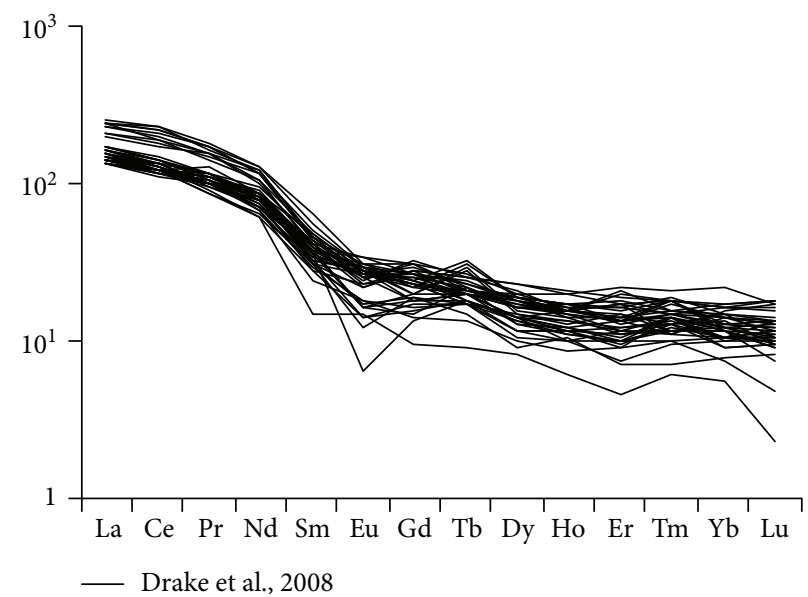

(d)

FIGURE 3: Chondrite-normalized [40] REE whole-rock concentrations of (a and b) the Götemar granite $(n=16)$, (c) greisen $(n=3)$ and for the calculated bulk vein $(n=28$, see text), and (d) rocks of the Transscandinavian Igneous Belt (TIB; $n=44)$ derived from Drake et al. [30].

has strong enrichment in light relative to heavy REE (Figure 3(a)) [38, 39], whereas the fine-grained granite and the aplite dykes have downward concave to relatively flat patterns (Figure 3(b)) [39]. Of the six minerals analysed for chemical elements, the REE concentrations are low in muscovite and K-feldspar (mean $\sum$ REE of 1.5 and $12 \mathrm{ppm}$, respectively), but they are typically orders of magnitude higher in fluorite (mean $\sum \mathrm{REE}=2156 \mathrm{ppm}$ ), apatite $\left(\right.$ mean $\left.\sum \mathrm{REE}=14080 \mathrm{ppm}\right)$, monazite (mean $\sum \mathrm{REE}$ $=45 \mathrm{wt} . \%)$, and zircon $\left(\sum \mathrm{REE}=3187 \mathrm{ppm}\right.$, Figures $4(\mathrm{a})$ and $4(\mathrm{~b}))$. Among the minerals, there is also a large variability in chondrite-normalized Eu anomalies and fractionation patterns, especially in the main accessory minerals that show patterns ranging from strong LREE enrichment in monazite to strong HREE enrichment in zircon, whereas fluorite and apatite display relatively flat patterns (Figures $4(\mathrm{a})$ and $4(\mathrm{~b})$ ).
4.2. Mineralogy and Chemistry of Greisen. The greisen is composed of quartz, muscovite, and fluorite. Minor minerals include biotite, K-feldspar, albite, chlorite, epidote, and pyrite. The main accessory mineral is calcite, whereas there is sporadic occurrence of topaz and fine-grained halite, sylvite, barite, hematite, rutile, monazite, zircon, chalcopyrite, and sphalerite. Bulk greisen has low REE concentrations (mean $=75 \mathrm{ppm}$ ) when compared to the Götemar granite and the TIB rocks, and it has chondrite-normalized patterns that are enriched in LREE (Figure 3(c)). On a mineralogical level, epidote, chlorite, topaz, K-feldspar, and muscovite are all LREE-enriched but with highly variable concentrations with the highest $\left.\sum \mathrm{REE}=1120 \mathrm{ppm}\right)$ in epidote (Figures 5(a) and 5(b)). These minerals, except chlorite, also have positive Eu anomalies (Figures 5(a) and 5(b)). Calcite has relatively flat REE fractionation patterns with a 


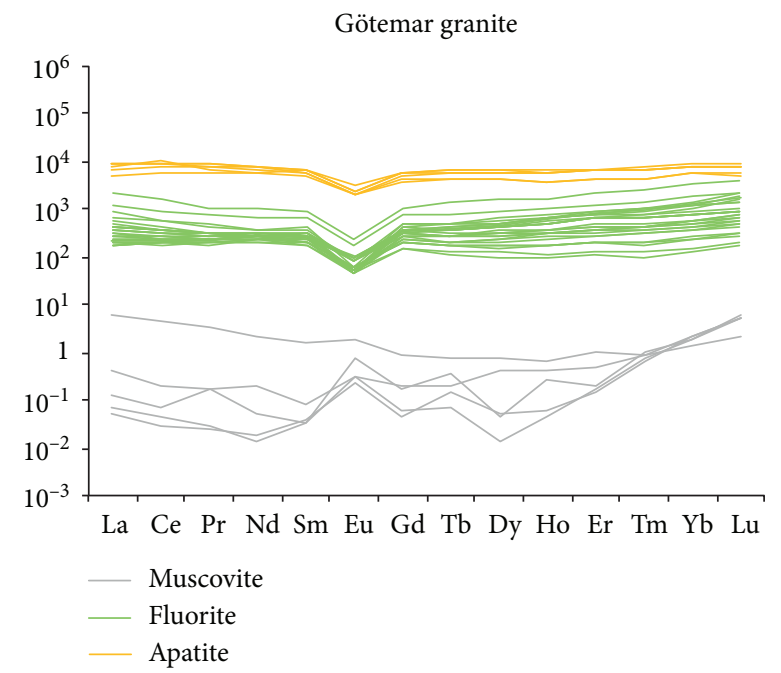

(a)

TIB

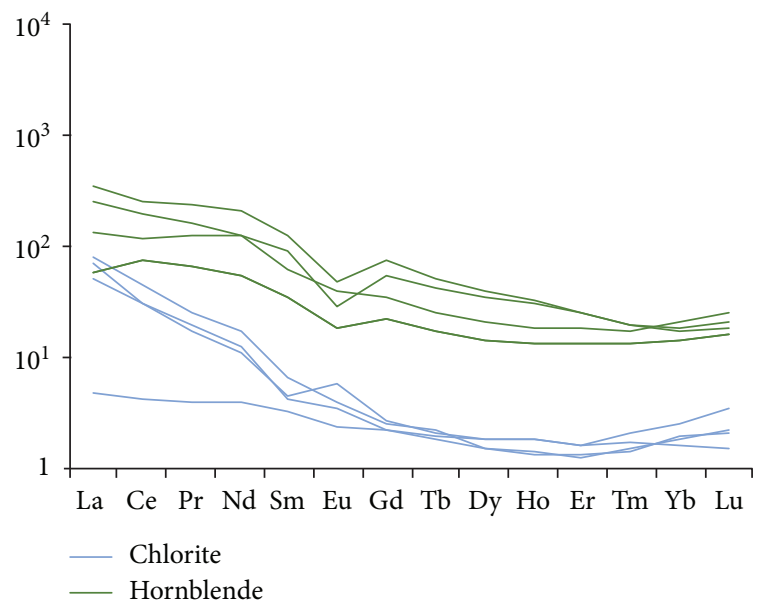

(c)

TIB

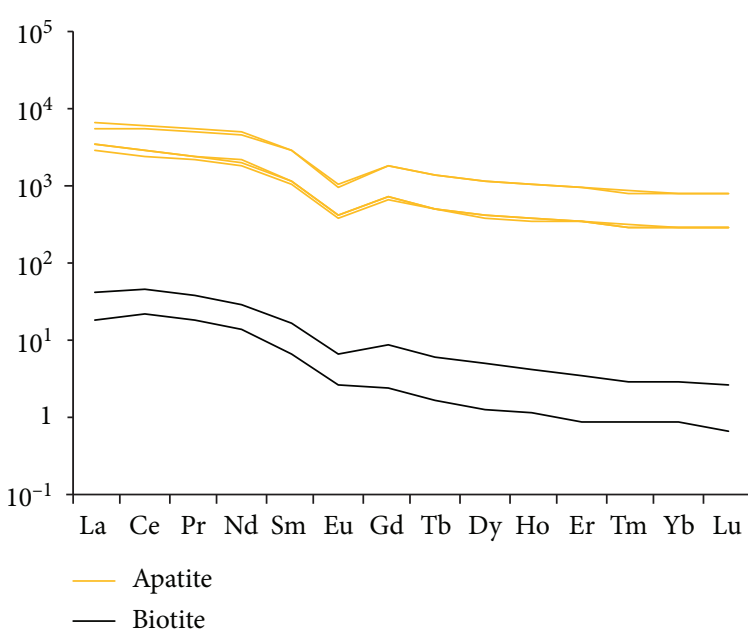

(e)

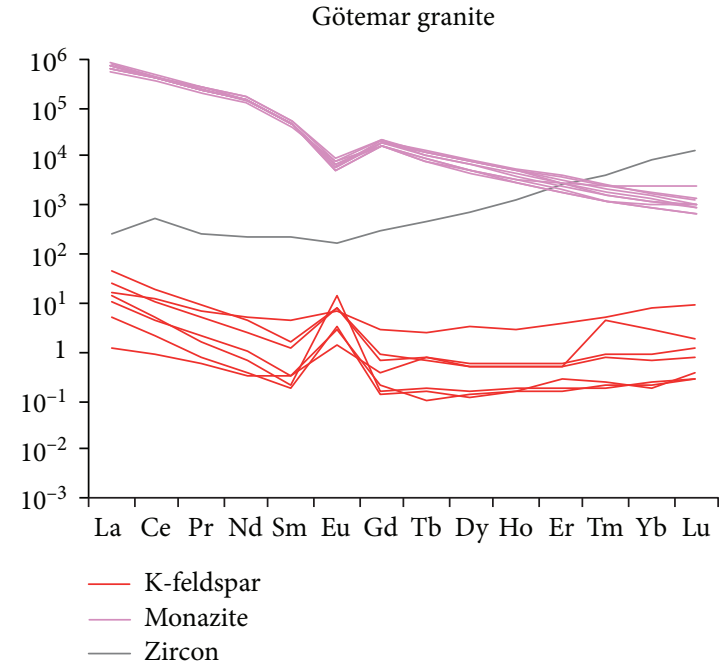

(b)

TIB

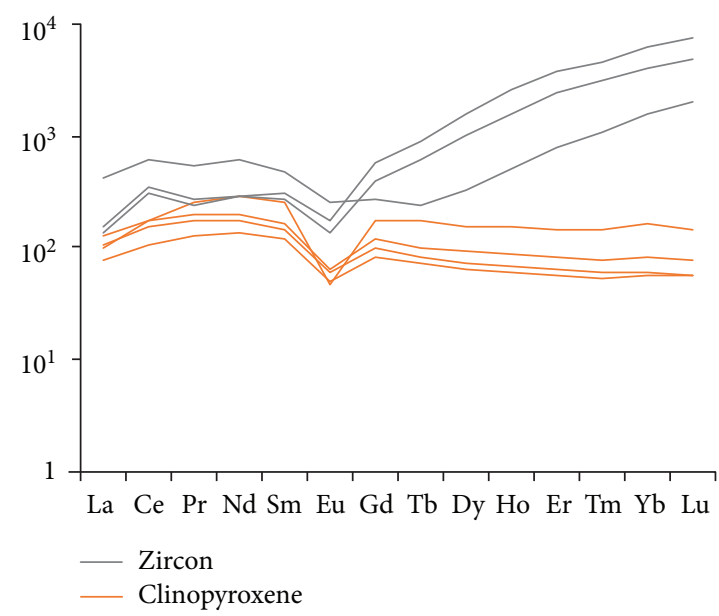

(d)

TIB

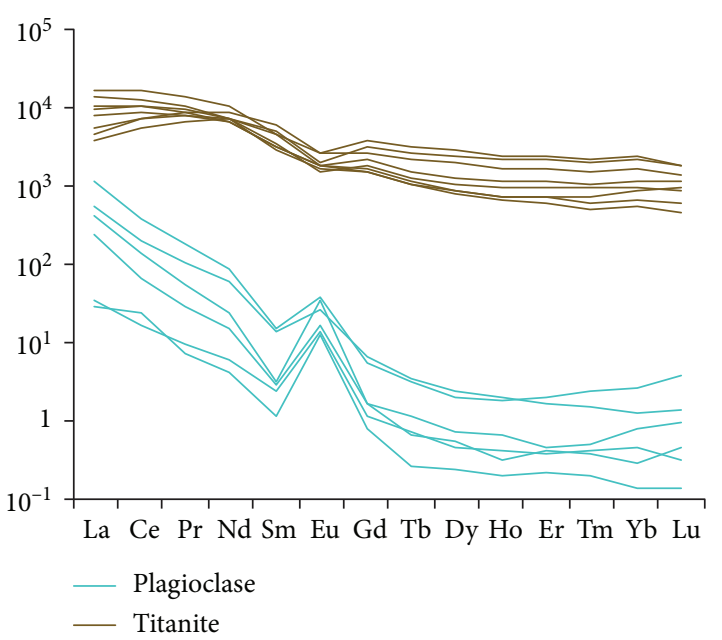

(f)

Figure 4: Chondrite-normalized [40] REE concentrations of minerals in (a and b) the Götemar granite and (c-f) the rocks of the Transscandinavian Igneous Belt (TIB). 
Greisen

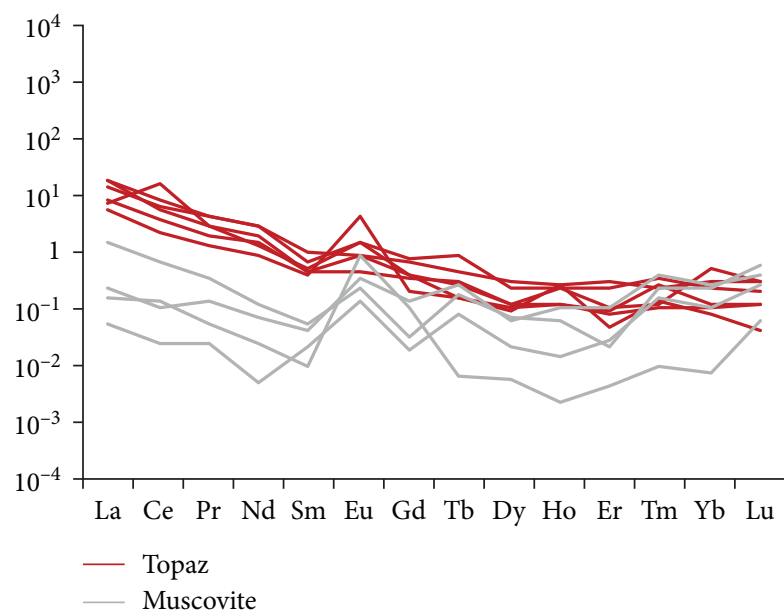

(a)

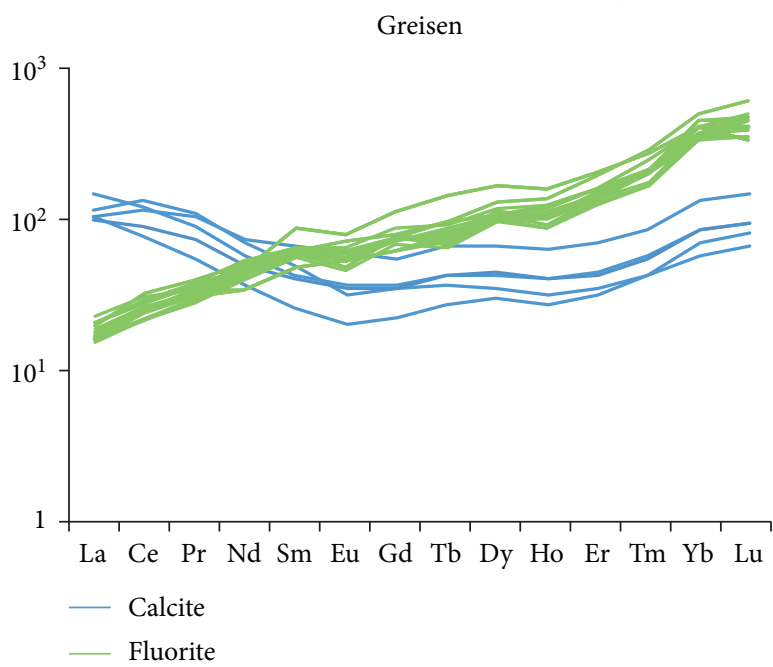

(c)

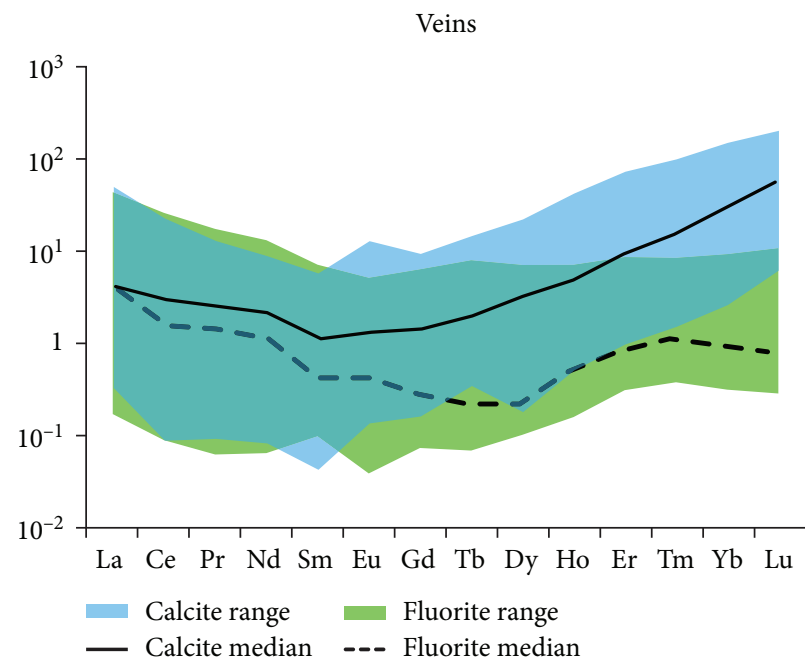

(e)
Greisen

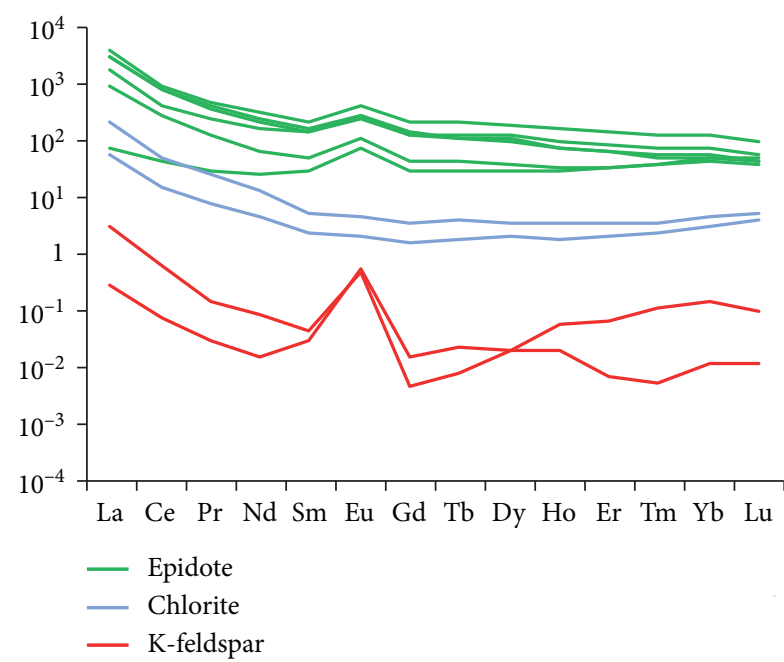

(b)

Veins

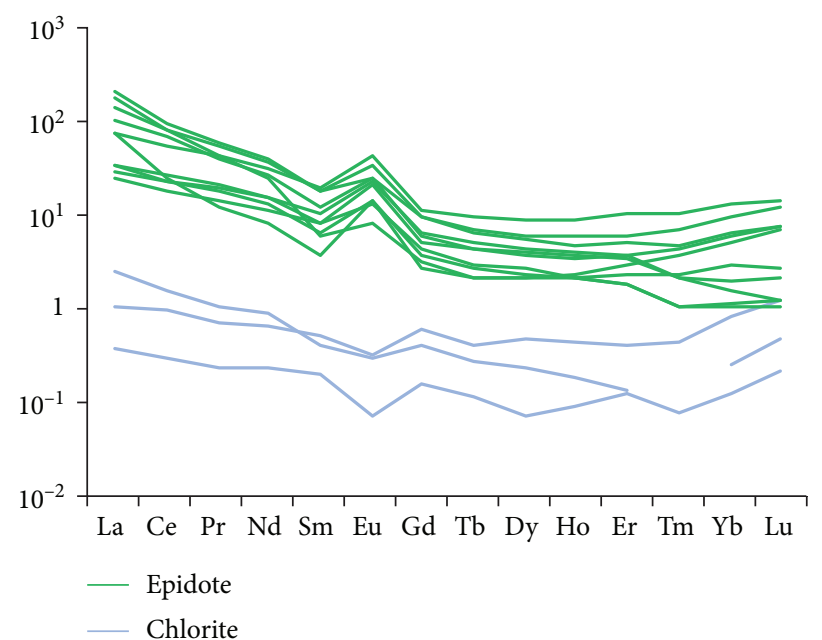

(d)

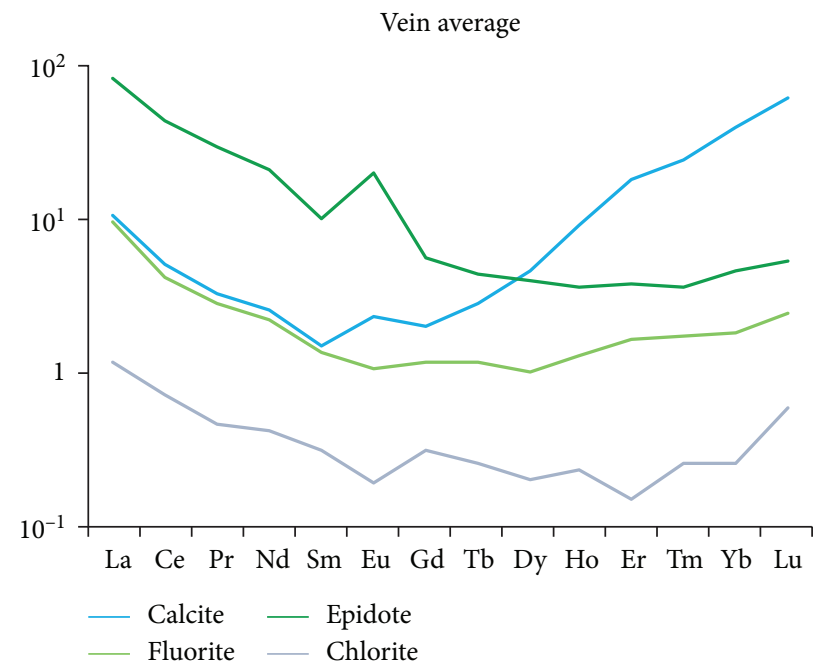

(f)

FIGURE 5: Chondrite-normalized [40] REE concentrations of minerals in (a-c) greisen and (d-f) veins. 
weak MREE depletion, whereas fluorite shows strong progressive enrichment with atomic number throughout the REE series (Figure 5(c)). Both calcite and fluorite are relatively rich in REE (median $\sum \mathrm{REE}=190$ and $210 \mathrm{ppm}$, respectively, Appendix B).

4.3. Mineralogy and Chemistry of Veins. The mineralogical composition of the veins is heterogeneous, and not all minerals in the assemblage are present in each specimen. Taking these features into account, it is possible to define that the vein paragenesis consists, in decreasing order, of quartz $(36 \%)$, calcite $(23 \%)$, epidote $(18 \%)$, chlorite $(16 \%)$, pyrite (4\%), and fluorite (3\%). There is a large variability in the concentrations and chondrite-normalized fractionation patterns of REE among the minerals. Median $\sum$ REE concentrations are highest in epidote $(61 \mathrm{ppm}$, range $=30-124)$ and lowest in chlorite and fluorite (1.5, range $=0.74-30$ and 2.8 , range $=0.65-2.3$, respectively), whereas calcite shows generally low (15.7) albeit highly variable values (4.6-51). Epidote is LREE-enriched (median $\mathrm{La}_{\mathrm{N}} / \mathrm{Yb}_{\mathrm{N}}=17$ ) and the only vein mineral with a distinctly positive Eu anomaly (Figure 5(d)). Also, fluorite and chlorite are LREE-enriched (median $\mathrm{La}_{\mathrm{N}} / \mathrm{Yb}_{\mathrm{N}} 3.9$ and 6.4, respectively), whereas calcite is HREEenriched (median $\mathrm{La}_{\mathrm{N}} / \mathrm{Yb}_{\mathrm{N}}=0.14$ and median $\mathrm{Pr}_{\mathrm{N}} / \mathrm{Yb}_{\mathrm{N}}=$ 0.07) and MREE-depleted (median $\mathrm{La}_{\mathrm{N}} / \mathrm{Tb}_{\mathrm{N}}=1.7$ and median $\mathrm{Tb}_{\mathrm{N}} / \mathrm{Yb}_{\mathrm{N}}=0.06$, Figures 5(d)-5(f)).

Determination of bulk-vein chemistry was challenging because the veins are heterogeneous in terms of the mineralogical composition. Therefore, bulk-vein chemistry was not assessed from measurements on whole-vein specimens, but it was calculated based on the proportion of mineral species and the median metal concentration determined for each of these minerals (Figure 3(c)). Based on this calculation, the veins have concentrations of $\mathrm{Fe}, \mathrm{Mg}$, $\mathrm{Mn}$, and $\mathrm{Sr}$ that were overall higher (Appendix A) but have $\sum$ REE (median $\left.=15 \mathrm{ppm}\right)$ that are much lower than in the bedrock of the area. The REE in the veins display a concave MREE-depleted fractionation pattern with a positive Eu anomaly (Figure 3(c)).

4.4. Fluid Inclusions in Greisen and Veins. Fluid inclusion analysis of quartz in greisen and veins revealed diverse compositions of several fluid types representing an early high-temperature stage and a later $\mathrm{CO}_{2}$-bearing stage. The main results are presented below, whereas additional details are given in Appendices $\mathrm{C}$ and $\mathrm{D}$.

4.4.1. Early Stage. Primary randomly scattered inclusions (Type $1_{p}$ ) in quartz \pm epidote \pm calcite \pm fluorite veins are composed of an aqueous $\mathrm{CaCl}_{2}-\mathrm{NaCl}-\mathrm{H}_{2} \mathrm{O}$ fluid with a high salinity (33.6-39.8 eq. mass $\% \mathrm{NaCl}$ ) and with halite and/or ferropyrosmalite $\left((\mathrm{Fe}, \mathrm{Mn})_{8} \mathrm{Si}_{6} \mathrm{O}_{15}(\mathrm{OH}, \mathrm{Cl})_{10}\right)$ and hematite as solid phases in coexisting inclusions. The salinity was deduced from the melting temperatures of halite [41] at $233-321^{\circ} \mathrm{C}\left(\right.$ mean $\left.=265^{\circ} \mathrm{C}\right)$. Total homogenization with the dissolution temperature of ferropyrosmalite recorded at $423-429^{\circ} \mathrm{C}\left(\right.$ mean $\left.=426^{\circ} \mathrm{C}\right)$ may be considered close to the formation temperature of the veins.
The majority of the halite-bearing inclusions display a partial (liquid+vapor+solid to liquid+solid) homogenization at $150^{\circ} \mathrm{C}$ followed by total homogenization at $233-321^{\circ} \mathrm{C}$ by the melting of halite (liquid+solid to liquid). Applying the method of intersecting isochores and liquidi for the $\mathrm{NaCl}-\mathrm{H}_{2} \mathrm{O}$ system as discussed by Bodnar [42] and combining the obtained temperature data with known experimental data, the approximate trapping pressure is estimated to be at 2-3.5 kbar.

The same type of inclusion also appears along secondary (Type $1_{s}$ ) fluid inclusion planes both in greisen and veins, where they were trapped after the fracturing of the quartz and a gradual decline in pressure to $1 \pm 0.5 \mathrm{kbar}$. The pressure is estimated according to the method of Bodnar [41] from total homogenization temperatures (liquid+solid to liquid) measured at $147-192^{\circ} \mathrm{C}\left(\right.$ mean $\left.=176^{\circ} \mathrm{C}\right)$ by halite melting, corresponding to a salinity of around 30 eq. mass $\%$ $\mathrm{NaCl}$ [41] and with a preceding partial homogenization (liquid+vapor+solid) in the range of $100-150^{\circ} \mathrm{C}$.

4.4.2. Late Stage. After further fracturing, the early highly saline stage was followed by an inflow of $\mathrm{CO}_{2}$ in the veins. The pressure initially at this stage is unknown, but molar volumes obtained from the homogenization and melting of $\mathrm{CO}_{2}$ inclusions in clusters (Type $2 \mathrm{~A}$ ) display a range from 47 to $55 \mathrm{~cm}^{3} /$ mole, which suggests a $\mathrm{CO}_{2}$ flow during a decreasing pressure to a level for the predominant condition of this stage. Secondary $\mathrm{CO}_{2}$ carbonic inclusions (Type 2A) with molar volumes close to $55 \mathrm{~cm}^{3} /$ mole were trapped contemporarily with secondary aqueous-carbonic inclusions (Type 2B) with $\mathrm{CO}_{2}$ molar volumes of $55-70 \mathrm{~cm}^{2} /$ mole and a salinity of $13.5-22$ eq. mass $\% \mathrm{CaCl}_{2}+\mathrm{NaCl}$ calculated from the gas hydrate dissociation $[43,44]$ and with secondary aqueous inclusions (Type 2C) with a similar salinity estimated from ice-melting temperatures [41]. The occurrence of these coexisting carbonic and aqueous fluid inclusions indicates that the fluids during the late fluidstage remained heterogeneous as two immiscible fluids and were trapped simultaneously as Type $2 \mathrm{~A}-\mathrm{C}$ inclusions. Sporadic interaction of the aqueous and carbonic fluids has resulted in the precipitation of nahcolite $\left(\mathrm{NaHCO}_{3}\right)$ in aqueous-carbonic inclusions with $>20 \mathrm{vol} . \% \mathrm{CO}_{2}$ phase and burbankite $\left((\mathrm{Na}, \mathrm{Ca})_{3}(\mathrm{Sr}, \mathrm{REE}, \mathrm{Ba})_{3}\left(\mathrm{CO}_{3}\right)_{5}\right)$ or calcite in aqueous-carbonic inclusions with $<20$ vol.\% $\mathrm{CO}_{2}$. An approximate pressure estimate of $0.3-0.7 \mathrm{kbar}$ can be made using the method by Roedder and Bodnar [45] with the intersection of isochores for the molar volumes $55-70 \mathrm{~cm}^{3} / \mathrm{mole}$ of the $\mathrm{CO}_{2}$-phases (secondary Type 2A and Type 2B) with the isochores for the aqueous phase represented by homogenization temperatures to liquid between 100 and $160^{\circ} \mathrm{C}$ and a salinity of $22 \mathrm{eq}$. mass $\% \mathrm{CaCl}_{2}+\mathrm{NaCl}$ for Types $2 \mathrm{~B}$ and $2 \mathrm{C}$.

4.5. Isotope Geochemistry and Geochronology. The results of the in situ $\mathrm{Rb}-\mathrm{Sr}$ geochronology of secondary mineral assemblages are shown in Figure 6 . Dating of muscovite \pm biotite \pm $\mathrm{K}$-feldspar \pm calcite \pm fluorite in three greisen samples yielded ages of $1433 \pm 6 \mathrm{Ma}, 1432 \pm 7 \mathrm{Ma}$, and $1431 \pm 5 \mathrm{Ma}$. Dating of biotite+calcite \pm epidote in two vein samples resulted in 
KLX06: 565 m: greisen

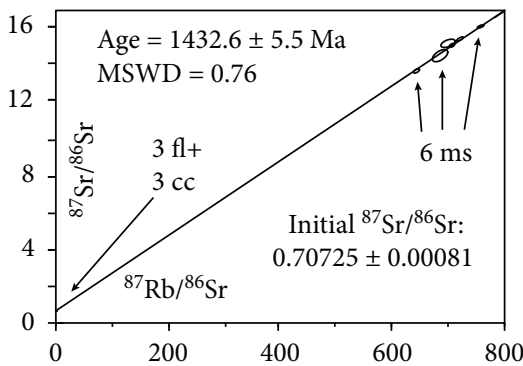

(a)

KLX10: 406 m: vein

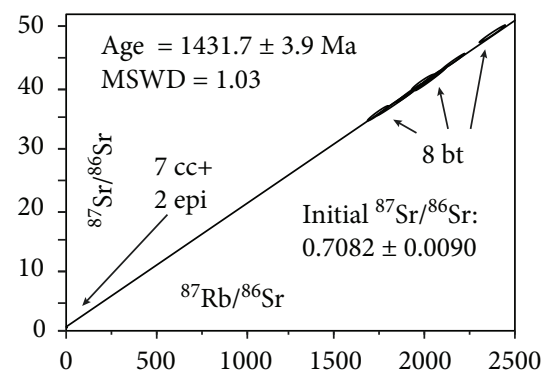

(d)
KLX06: 572 m: greisen

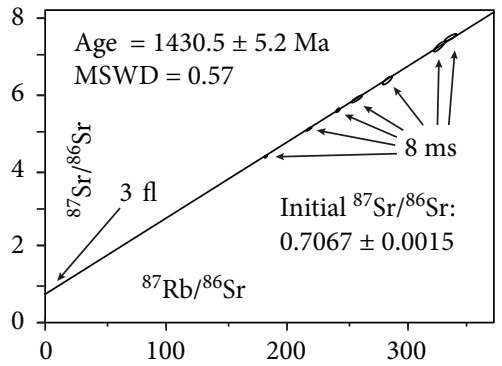

(b)

KLX10: 895 m: vein

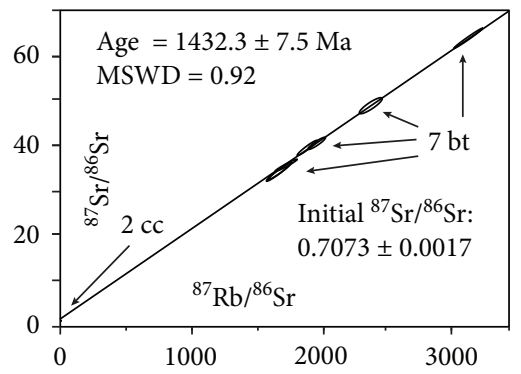

(e)
KLX06: 593 m: greisen

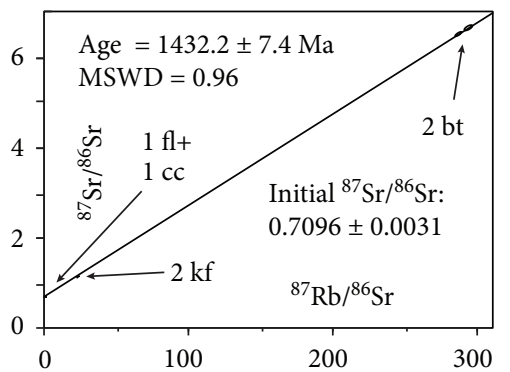

(c)

KLX06: 593 m: greisen

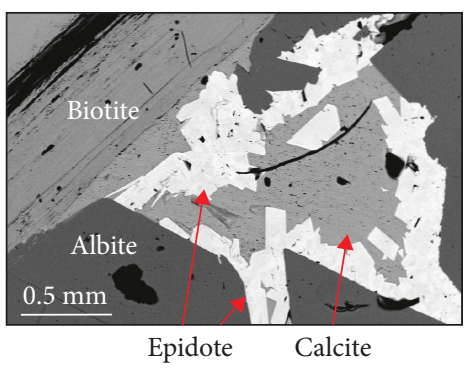

(f)

FIGURE 6: Isochrons of $(\mathrm{a}-\mathrm{c})$ greisen and $(\mathrm{d}-\mathrm{e})$ vein samples dated by in situ Rb-Sr dating in this study, with ages in $1 \mathrm{~s}$. (f) BSE microphotograph of epidote and calcite with albite and biotite in greisen sample KLX06: $593 \mathrm{~m}$. bt=biotite, ms=muscovite, $\mathrm{kf}=\mathrm{K}$-feldspar, $\mathrm{cc}=$ calcite, $\mathrm{fl}=$ fluorite, and epi=epidote.

ages of $1432 \pm 8 \mathrm{Ma}$ and $1432 \pm 4 \mathrm{Ma}$. The radiometric data is contained in Appendix E.

The isotopic systems $\delta^{34} \mathrm{~S},{ }^{87} \mathrm{Sr} /{ }^{86} \mathrm{Sr}$, and $\delta^{18} \mathrm{O}$ versus $\delta^{13} \mathrm{C}$ have previously been used in this kind of settings to distinguish between veins belonging to different geological eras $[26,46]$. Consequently, $\delta^{34} S$ values of pyrite in veins and greisen, $\delta^{18} \mathrm{O}$ and $\delta^{13} \mathrm{C}$ values of calcite in the veins, and ${ }^{87} \mathrm{Sr} /{ }^{86} \mathrm{Sr}$ values of calcite and fluorite in the veins and greisen were analysed in some samples and collected from the literature in others (Figure 7). For each of these isotopic systems, the samples showed a small variability (Figure 7). Appendix F contains the stable isotopic data.

\section{Discussion}

5.1. Genetic Links. The coupling of the hydrothermal greisen and vein mineralization to fluids emanating from the Götemar granite was strongly supported by age determinations, as in situ $\mathrm{Rb}$-Sr age analyses of three greisen and two vein samples representative for these mineralizations have a narrow interval of $1432 \pm 8 \mathrm{Ma}$ that overlap with the emplacement age $(1433 \pm 10 \mathrm{Ma})$ of the Götemar granite [20]. In addition, the veins and greisen show isotopic ratio signatures $\left({ }^{87} \mathrm{Sr} /{ }^{86} \mathrm{Sr}\right.$ of calcite and fluorite, $\delta^{34} \mathrm{~S}_{\mathrm{VCDT}}$ of pyrite, and $\delta^{18} \mathrm{O}_{\mathrm{VPDB}}$ and $\delta^{13} \mathrm{C}_{\mathrm{VPDB}}$ of calcite) that overlapped and were significantly different to the corresponding signatures of younger veins formed in the Neoproterozoic and Phanerozoic (Figure 7) eras. Thus, there is strong evidence of a genetic link between greisen and vein formation and granite emplacement that allows interpretation of REE transport and fractionation along this hydrothermal system. Geophysical modelling has revealed that the Götemar granite stretches southwards in the subsurface, reaching the northernmost KLX boreholes (Figure 1), where abundant micarich greisen veins indicate close proximity to the granite. However, influence from the contemporary Uthammar granite [47] further south of Laxemar (Figure 1) cannot be entirely excluded. Strategies for future studies to distinguish between these two magma sources may include quartz trace element composition, as utilized in [48].

5.2. Physicochemical Evolution of the Hydrothermal System. No $\mathrm{pH}$ estimates exist for the hydrothermal fluids forming the greisen and veins, but several observations suggest that it is unlikely that fluids avoided extensive rock buffering for up to two $\mathrm{km}$ in the thin pathways of the veins: (i) primary minerals in the wall rock adjacent to the veins are extensively altered [29]; (ii) the fluid inclusions were characterized by moderate to high salinity, $\mathrm{Na}$-, $\mathrm{Ca}$-, and $\mathrm{K}$-chloridedominated compositions, and $\mathrm{Na}, \mathrm{Ca}, \mathrm{Fe}$, or $\mathrm{Si}$ in the solid phases indicating that feldspar and possibly pyroxene, biotite, and magnetite contributed with chemical species throughout greisenization and veining; and (iii) at high fluid/rock ratios, greisen mineral assemblages are dominated by topaz-quartz [49], a feature not observed in the study area where the amount of topaz in the investigated greisen was very low. Boiling, or effervescence, is another process that may either decrease or increase fluid $\mathrm{pH}$ depending on the acidity of the gas phase released by unmixing $[50,51]$. The lack of a vapor phase in the primary fluid inclusions and the absence 


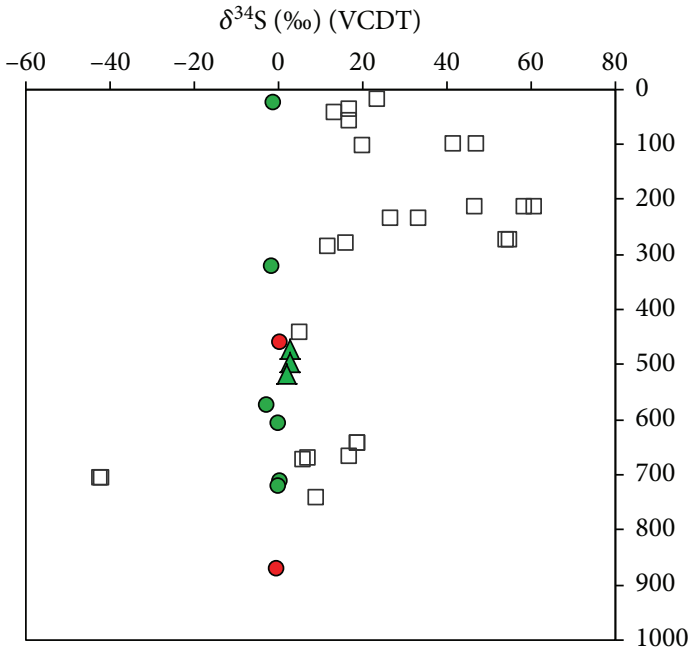

Mezoproterozoic generation:

Vein $(\bigcirc)$ and greisen $(\triangle)$ specimens included in this study

Vein $(\bigcirc)$ and greisen $(\triangle)$ specimens from Drake and Tullborg (2009)

Other generations:

Neoproterozoic $(\triangle)$, Paleozoic $(\square)$, and post-Paleozoic $(\diamond)$ from Drake and Tullborg (2009)

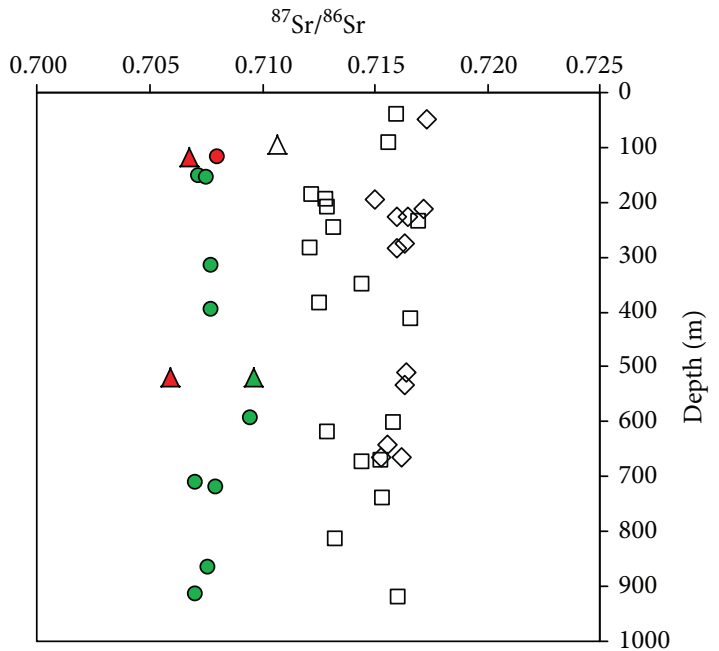

Mezoproterozoic generation:

Vein $(\bigcirc)$ and greisen $(\triangle$ specimens included in this study

Vein $(\bigcirc)$ and greisen $(\triangle)$ specimens from Drake and Tullborg (2009)

Other generations:

Neoproterozoic $(\triangle)$, Paleozoic $(\square)$, and post-Paleozoic $(\diamond)$ from Drake and Tullborg (2009)

(a)

(b)

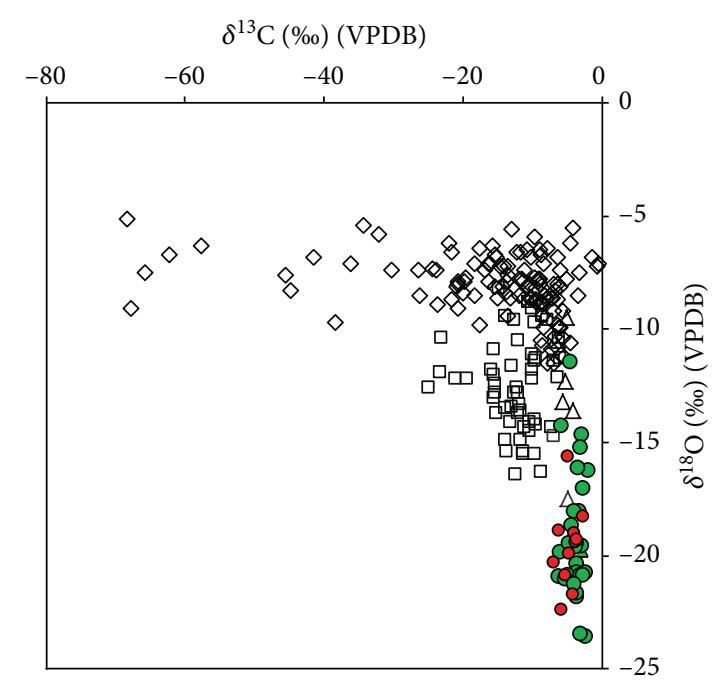

Mezoproterozoic generation:

Vein $(\bigcirc)$ and greisen $(\triangle)$ specimens included in this study

Vein $(\bigcirc)$ and greisen $(\triangle)$ specimens from Drake and Tullborg (2009)

Other generations:

Neoproterozoic $(\triangle)$, Paleozoic $(\square)$, and

post-Paleozoic $(\diamond)$ from Drake and Tullborg (2009)

(c)

FIGURE 7: Isotopic composition of Mezoproterozoic minerals compared with isotopic composition of minerals of Neoproterozoic, Paleozoic, and post-Paleozoic minerals occurring at the site, collected in this study, and collected previously in Drake and Tullborg [26]. 
of a salinity increase with a decreasing homogenization temperature suggest that the formation depth of greisen and veins at $4-8 \mathrm{~km} \mathrm{[21]} \mathrm{was} \mathrm{too} \mathrm{deep} \mathrm{for} \mathrm{boiling} \mathrm{to} \mathrm{occur.} \mathrm{Taken}$ together, this implies a system with a low fluid/rock ratio where fluid $\mathrm{pH}$ was extensively buffered by the wall rock at both greisen and vein stages. The $\mathrm{pH}$ buffering was possibly accompanied by increasing oxygen fugacity, $f \mathrm{O}_{2}$, as the fluids dispersed into the veins, as indicated by $\mathrm{Ce}$ and $\mathrm{Eu}$ anomalies in calcite and fluorite (Appendix $\mathrm{H}$ ).

Maximum temperatures of $430^{\circ} \mathrm{C}$ in primary fluid inclusions in the veins represent the lower end of the decreasing thermal gradient from the magmatic crystallization stage through greisenization and subsequent vein formation. The crystallization temperature of the Götemar granite is here tentatively estimated at about $945^{\circ} \mathrm{C}$ by Ti-in-zircon geothermometry [52] using the trace element composition of one zircon grain (Appendix B). This single-spot estimate is rough as it cannot account for intra- and intercrystalline Ti variation that can be substantial in zircon [53], but it is still reasonable given that A-type granite (with the exception of alkaline granites) crystallization temperatures are normally above $900^{\circ} \mathrm{C}$ [54]. The greisen formation temperature is estimated at about $460-480^{\circ} \mathrm{C}$ by two-feldspar thermometry [55] based on the $\mathrm{K}_{2} \mathrm{O}, \mathrm{Na}_{2} \mathrm{O}$, and $\mathrm{CaO}$ composition of coexisting $\mathrm{K}$-feldspar and plagioclase (Appendix $\mathrm{G}$ ) and a pressure set to $2 \mathrm{kbar}$ representing the established granite intrusion depth of $4-8 \mathrm{~km}$ [22]. The uncertainty of the temperatures yielded by this feldspar geothermometer has been estimated at $\pm 30^{\circ} \mathrm{C}$ [55]. Moreover, the sensitivity for compositional differences is high. The low concentrations of $\mathrm{Na}_{2} \mathrm{O}$ and $\mathrm{CaO}$ in $\mathrm{K}$-feldspar and $\mathrm{K}_{2} \mathrm{O}$ and $\mathrm{CaO}$ in the albite plagioclase end member approaching detection limits of the SEM-EDS analysis imply that the uncertainties are likely higher and that the temperature range thus should be treated with caution. A difference of one order of magnitude for either of these compounds causes temperature shifts of up to $100^{\circ} \mathrm{C}$, with $\mathrm{Na}_{2} \mathrm{O}$ and $\mathrm{CaO}$ in $\mathrm{K}$-feldspar being the most sensitive. The indicated temperatures are nonetheless in the range of $400-600^{\circ} \mathrm{C}$ required for greisenization [56].

5.3. General REE Behavior. The REE concentration estimated for the bulk vein was only $15 \mathrm{ppm}$, which is three times lower than that for greisen, more than an order of magnitude lower than that for the TIB wall rock, and approximately 20 times lower than that for the anorogenic granite. This is a reflection of the low $\sum$ REE content of all the REE-bearing minerals composing the veins, including calcite (median $=15.7 \mathrm{ppm})$, epidote (61 ppm), fluorite (2.8 ppm), and chlorite (1.5 ppm). The low REE concentrations of these vein minerals become particularly obvious when comparing with the concentrations in the corresponding minerals in granite (median fluorite: $2156 \mathrm{ppm}$ ) and greisen (calcite: $190 \mathrm{ppm}$, epidote: $1120 \mathrm{ppm}$, fluorite: $210 \mathrm{ppm}$, and chlorite: $59 \mathrm{ppm}$, Appendix A; Figures 8(a)-8(d)). Although these features may be partly explained by transport into the veins of REEpoor fluids such as meteoric water or host-rock brines, such a mechanism seems to have been minor or insignificant considering that (i) fluid mixing was sparsely encountered, (ii) no clear trends in the REE patterns can be linked to wall-rock influence, and (iii) the diverging REE patterns between the different deposition stages and among the minerals at each stage suggest that fluid transport and deposition mechanisms dominated REE fractionation. Hence, the low REE content in the veins strongly suggests that the conditions during intrusion of the granite did not favor extensive REE partitioning into the fluids that were separated and transported into fractures of the country rock, despite that these fluids contained ligands with a capacity to complex and transport the REE including (i) fluoride as evidenced by the occurrence of fluorite and topaz in greisen and fluorite in the veins (Figure 2), and that fluorine is enriched (on average by $11 \%$ ) in the altered wall-rock zone around the veins (typically red stained) relative to fresh rock [30]; (ii) carbonate as evidenced by calcite in both greisen and veins (Figure 2); and (iii) chloride as evidenced by the highly saline fluids and the presence of halite and sylvite in greisen.

The data thus point to a large retention of REE in the granite. This is explained mainly by the abundant incorporation of these metals into the accessory minerals fluorite, monazite, and apatite (Figures 4(a) and 4(b)). The high concentrations in monazite and apatite indicate that the retention was primarily a consequence of the high uptake by phosphates [6], whereas the high concentrations in fluorite also show that this mineral constituted a significant trap at the magmatic stage, in line with observations elsewhere that fluorite can incorporate significant quantities of REE from a melt [57]. Unlike the phosphates, fluorite was also abundant in greisen and veins, with an overall pattern of decreasing REE concentrations in the sequence granite $>$ greisen $>$ veins (Figure 8(a)).

5.4. Fractionation Patterns of REE in Greisen and Veins. The REE displayed diverse and distinct fractionation patterns among the vein minerals. Calcite was MREE depleted and HREE enriched (Figures 5(e) and 5(f)), epidote was enriched in the LREE (Figure 5(d)), and fluorite was on average MREE depleted (Figure 5(f)). This shows that albeit overall tiny fluxes of REE into the veins, the vein minerals had in a distinct manner captured and fractionated the REE.

The morphological features suggested that epidote occurred typically, although not exclusively, along the borders of the veins (Figures 2(a)-2(d)). There is thus evidence that of the two major REE-carrying minerals in the veins-epidote and calcite-the former was generally precipitated earlier than the latter. If assuming that the calculated REE pattern of the whole vein (Figure 3(c)) represented the bulk fluid REE composition, epidote precipitation caused a preferential removal of LREE ( $~ 85 \%$ of the LREE pool, Figure $8(\mathrm{f})$ ), reflecting the consistent enrichment of LREE over HREE in the epidote specimens (Figure 5(d)). Subsequent calcite precipitation, preferentially in the middle of the veins (Figures 2(a)-2(d)), consequently occurred from residual fluids depleted in REE in general and in LREE in particular, causing the calcite to attain low REE concentrations characterized by progressive HREE enrichment (Figures 5(e) and 5(f)) with up to $92 \%$ of the HREE pool being trapped in calcite (Figure $8(\mathrm{f})$ ). This fractionation phenomenon was most likely intensified by the tendency of 


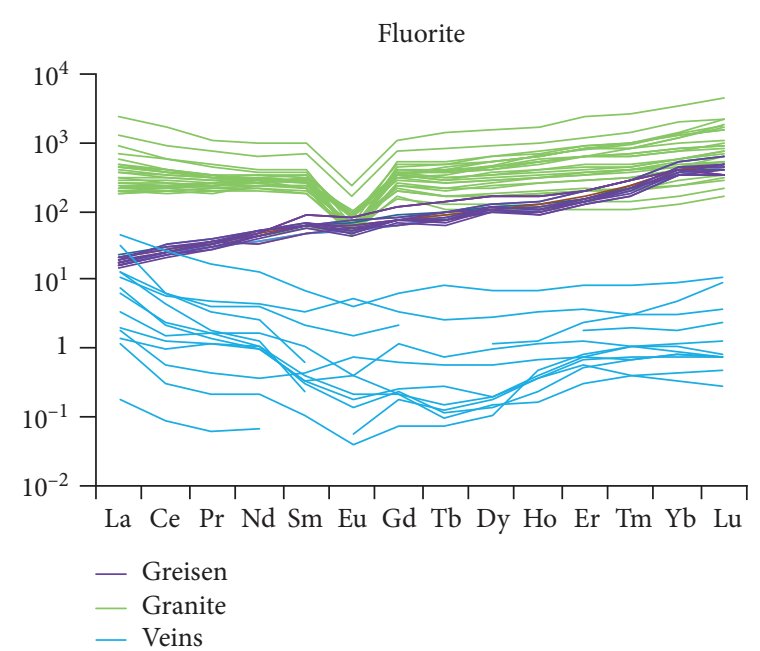

(a)

Calcite

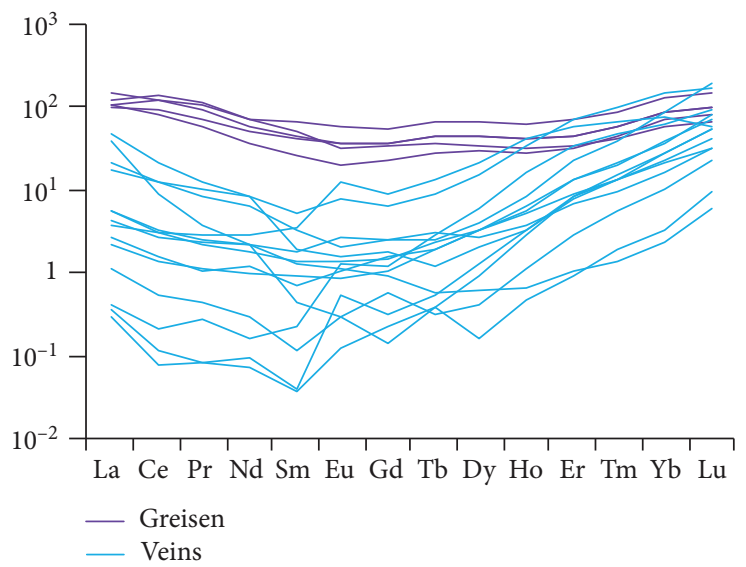

(c)

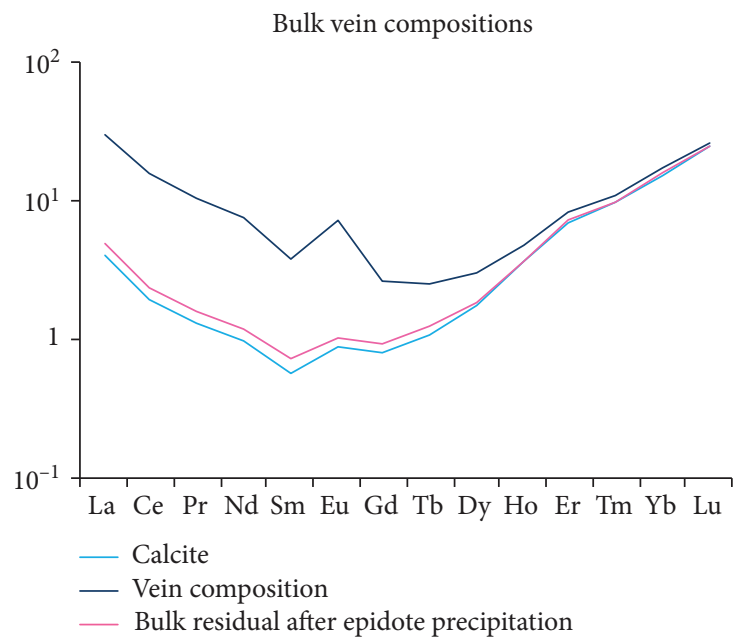

(e)

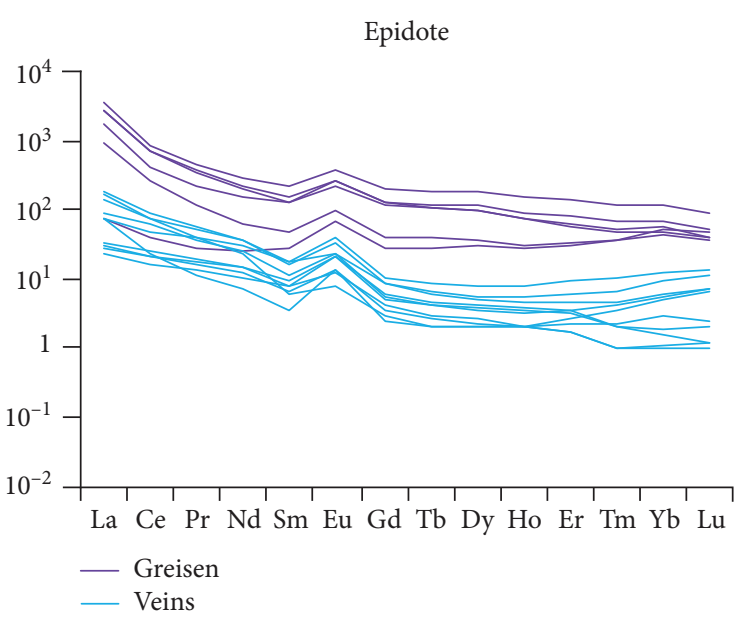

(b)

Chlorite

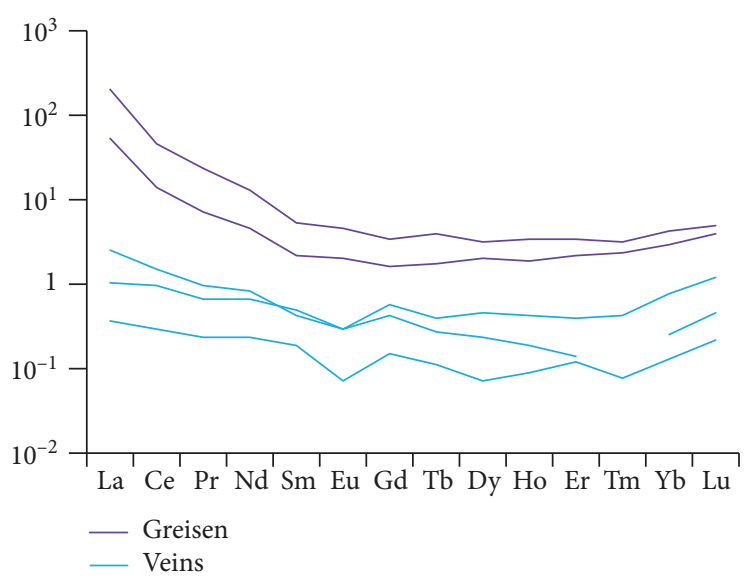

(d)

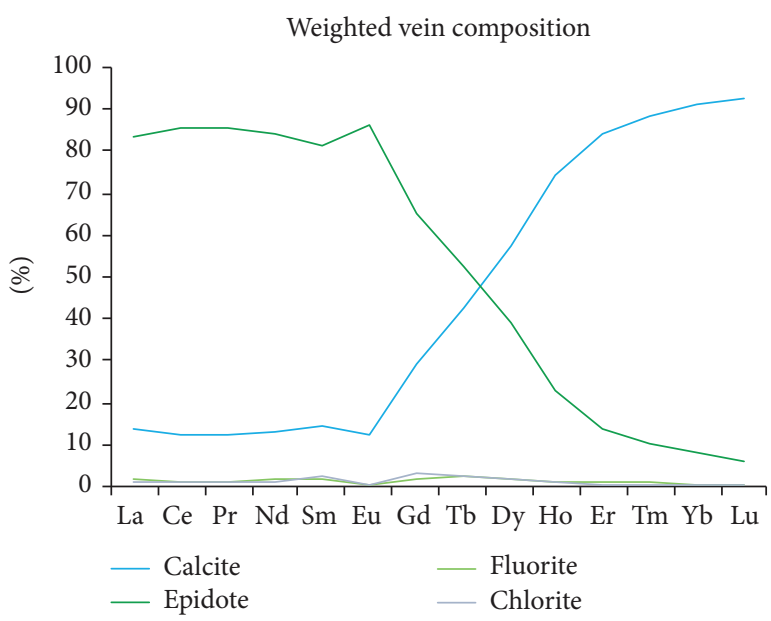

(f)

FIgURE 8: Comparison of chondrite-normalized REE concentrations in different sample types in (a) fluorite, (b) epidote, (c) calcite, and (d) chlorite. (e) Chondrite-normalized [40] REE concentrations calculated for bulk vein, the residual remaining after the hypothetical withdrawal of epidote, and the contribution by calcite after epidote withdrawal (the epidote withdrawal and calcite contribution were calculated by multiplying the average REE concentrations for the mineral with its estimated mode in the veins), and (f) REE composition of vein minerals normalized to the estimated mineral mode of the veins. 
LREE to preferentially become incorporated in epidote as compared to calcite, that is, the REE partitioning for epidote/calcite is typically high for LREE (approximately 100) and frequently decreases across the REE series and reaches values of approximately 1 for HREE $[58,59]$. The remaining two REE-carrying minerals in the veins-fluorite and chlorite-were less abundant and had considerably lower $\sum$ REE concentrations than calcite and epidote (Figure 5(f)), and therefore were negligible in terms of the REE budget of the veins (Figure 8(f)).

The REE patterns of vein calcite and fluorite were opposite to those in greisen. In the veins, calcite was a major REE depositional agent and displayed HREE enrichment, whereas fluorite showed no HREE enrichment as compared to LREE (Figures 5(e) and 5(f)). In greisen, fluorite was a major REE depositional agent and displayed HREE enrichment, whereas calcite had a flat pattern with a slight MREE depletion (Figure 5(c)). In addition, the HREE enrichment of greisen fluorite (Figure 5(c)) was also in contrast to the flat REE trend of fluorite within the Götemar granite (Figures 4(a) and 8(a)). This shows that mineral-specific REE partitioning at the hydrothermal temperatures prevailing at the greisen and vein formation was not a major control of REE fractionation patterns within individual minerals. At the specimen scale for both greisen and veins, the REE patterns of individual minerals were not correlated with coprecipitating mineral paragenesis. For example, there was a similar HREE enrichment of calcite both in vein samples with and without epidote and/or fluorite. The most likely explanation for this feature is the sampling limitations set by the drill-core diameter, that is, only a small part of the entire vein was collected in a single sample. Consequently, major minerals in terms of both relative abundance and REE capture, such as calcite and epidote, most likely occurred in all vein systems although they were not identified in every single sample.

5.5. REE Speciation in the Hydrothermal Fluids. Assessment of the complexation of REE transported in the hot and saline late-magmatic hydrothermal fluids emanating from the granite intrusion is challenging. The existence of abundant calcite and to some degree fluorite in the veins (and opposite proportions in the greisen) and $\mathrm{NaCl}$ - and water-rich inclusion types in the greisen and veins means that a variety of transporting and/or depositional REE ligands such as chloride, fluoride, hydroxide, and carbonate existed and may have contributed to the ultimate fate of $\operatorname{REE}[5,10]$. Additionally, the low $\sum$ REE concentrations in greisen and particularly the veins indicate low REE concentrations in the source fluids, further complicating the evaluation of REE complexation during transport and deposition. Furthermore, there is the decreasing stability of REE complexes with decreasing temperatures [5]. The temperature constraints indicate a decreasing gradient of at least $300-400^{\circ} \mathrm{C}$ from granite to greisen and an additional lowering by $30-50^{\circ} \mathrm{C}$ towards the initial vein stage. This means that simple cooling may have been a significant depositional mechanism as well. Despite this, general assessments of REE complexation can be made.
Chloride is typically the most abundant REE transporting ligand in hydrothermal systems due to the high solubility of chloride minerals [11]. In neutral to slightly acidic hydrothermal solutions, chloride complexes are more stable for LREE than HREE, while under strongly acidic conditions the complexation strength is reversed with more stable complexes for HREE [5, 60]. The strong indications that the Cl-rich greisen and vein fluids most likely had a circumneutral $\mathrm{pH}$ mean that they could have contributed to keep LREE preferentially in solution as $\mathrm{Cl}^{-}$complexes. The predominance of chloride complexation typically increases to higher $\mathrm{pH}$ with increasing temperature [5], which suggests that the most substantial REE-chloride aqueous transportation occurred close to the granite, as corroborated by high salinities in the high-temperature fluid inclusions [12].

High $\mathrm{Y}$ to Ho ratios in fluorite in the veins (70-146, median $=85)$, granite $(72-79$, median $=75)$, and greisen $(24-57$, median $=44)$ as compared to the corresponding ratio in chondrite (28) indicate REE-fluoride complexation in the source fluids [61] because of the stronger partitioning of $\mathrm{Y}$ than Ho (and other REE) in complexes with fluoride $[62,63]$. However, the increase in $\mathrm{Y} / \mathrm{Ho}$ in the veins may also have been influenced by F-input via biotite alteration [64] and, in particular, increased stability of $\operatorname{REEF}^{2+}$ at the lower temperature stage [65]. The extent of REE complexation with fluoride can therefore not be directly assessed, but as fluoride typically is a depositional rather than a transporting ligand [11] and as the fluorite contents in the veins was low, it is likely that fluoride did not contribute significantly to transport REE beyond the greisen stage.

The low REE concentrations in the studied hydrothermal system and the naturally low hydroxide contents in acidic fluids suggest that hydroxide was not a significant transporting agent at early greisen stages where the combination of low $\mathrm{pH}$ and temperatures above $350^{\circ} \mathrm{C}[11,12]$ disables complex stability. Hydroxyl REE complexation was likely also insignificant during vein formation since the hydroxyl species is only considered to impact REE mobility below $200^{\circ} \mathrm{C}[12]$.

Carbonate ligands have been shown to form strong complexes with MREE and HREE at both high $\left(600-800^{\circ} \mathrm{C}\right.$; [66]) and low $\left(25^{\circ} \mathrm{C}\right.$; [67]) PT conditions, whereas data for REE partitioning of carbonate complexation is absent in the moderate hydrothermal regime [5]. Modelling of REE speciation and fluid/calcite partitioning in $\mathrm{H}_{2} \mathrm{O}-\mathrm{NaCl}-\mathrm{CO}_{2}$ solutions in temperatures ranging between 100 and $400^{\circ} \mathrm{C}$ predicts bicarbonate or carbonate complexation at low salinity but suppresses carbonic species in favor of chloride complexes at high salinity [12]. In our vein system, with fluids rich in $\mathrm{NaCl}$ and with temperatures up to $430^{\circ} \mathrm{C}$, calcite precipitation was impeded despite probable calcite saturation [12] and high $\mathrm{CO}_{2}$ pressure until fluid temperature and pressure successively decreased enough to enable $\mathrm{H}_{2} \mathrm{CO}_{3}$ dissociation into the aqueous species [68]. This feature is consistent with the low abundance of calcite in greisen and also implies that carbonate complexation had a negligible influence on REE fractionation at the high-temperature hydrothermal stages. The presence of burbankite in vein fluid inclusions shows, however, that REE accompanied carbonates in the vein 
system, at least towards the distal (lower PT) parts of it. High fluid salinity makes HREE-carbonate complexes progressively less stable compared to LREE-carbonate complexes and thus causes preferential HREE enrichment in calcite [12], which is consistent with the typical HREE enrichment measured in our vein calcites (Figures 5(e), 5(f), and 8(c)). Hence, this mechanism coupled with the preferential accumulation of LREE in epidote (Figures 5(f), 8(b), and 8(f)) explains the characteristic HREE enrichment in the vein calcites (Figures 5(e), 5(f), and 8(c)). HREE enrichment of the kind shown here for vein calcite has only in rare occasions been reported in sedimentary [69] and igneous settings [70]. Our findings show that coupled complexation-driven REE retention and preferential REE partitioning into preor coprecipitating phases (in this study epidote) may constitute important processes in precipitating calcite with high HREE to LREE ratios from REE-deficient hydrothermal greisen and vein systems.

\section{Conclusions}

We have performed a detailed study on transport and fractionation of REE by fluids generated by a Mesoproterozoic granite intrusion and ultimately producing greisen dispersed in thin veins in Paleoproterozoic granitoids. The genetic link between granite, greisen, and veins was determined by high spatial resolution $\mathrm{Rb}-\mathrm{Sr}$ dating and stable isotopic signatures. Fluid-inclusion microthermometry revealed that multiple pulses of moderately to highly saline aqueous to carbonic solutions caused greisenization and vein formation at temperatures ranging from $430^{\circ} \mathrm{C}$ at the early hydrothermal stage in the veins to above $200-250^{\circ} \mathrm{C}$ throughout. Although the veins may have received REE-poor fluids such as meteoric water or host-rock brines, there is support for a major portion of hydrothermal fluids dispersed from the granite intrusion into the veins. Hence, the low $\sum$ REE concentrations of the veins (15 ppm) and also of the greisen (75) as compared to the granite (320) were explained by limited REE partitioning into the hydrothermal fluids that were separated and transported from the granite intrusion into fractures of the country rock. The data thus point to a large retention of REE in the granite, explained mainly by abundant REE incorporation into the accessory minerals fluorite, monazite, and apatite.

Despite the low REE concentrations in the veins and greisen, the minerals composing these materials displayed diverse and distinct REE-fractionation patterns. In particular, the REE features of vein calcite and fluorite were opposite to those in greisen. In the veins, calcite displayed HREE enrichment and fluorite showed no HREE enrichment as compared to LREE, whereas in greisen calcite had a flat pattern with a slight MREE depletion and fluorite displayed HREE enrichment. In addition, the HREE enrichment of greisen fluorite was in contrast to the flat REE trend of fluorite within the Götemar granite. This shows that mineralspecific REE partitioning at the hydrothermal temperatures prevailing at the greisen and vein formation was not a major control of REE-fractionation patterns within individual minerals. The HREE enrichment of vein calcite is a relatively rare feature. It is explained largely by initial epidote precipitation that trapped much of the LREE leaving a residual fluid enriched in HREE from which calcite precipitated, with a likely contribution from carbonate complexation at the vein stage as compared to suggested chloride complexation prior, or up to, greisenization.

\section{Data Availability}

The major and trace element data, as well as fluid-inclusion microthermometric, radiometric, and stable isotope data of the bulk materials and minerals used to support the findings of this study are included within the article or within the supplementary information files in Appendices A-H.

\section{Conflicts of Interest}

The authors declare that there is no conflict of interest regarding the publication of this article.

\section{Acknowledgments}

We are thankful to the Swedish Nuclear Fuel and Waste Management Co. (SKB) and the Joint Research and Development Platform at the Nova Centre for University Studies (Nova FoU) for providing us opportunities to process existing data and materials owned by SKB. Thanks are due to Matthias Konrad-Schmolke for assisting in SEM analysis. Vetenskapsrådet (contract 2017-05186 to H.D.) and Svenska Forskningsrådet Formas (contract 2017-00766 to H.D.) are thanked for financial support.

\section{Supplementary Materials}

Supplementary materials include major and trace element compositions of bulk rocks in Appendix A, major and trace element compositions of minerals in Appendix B, fluidinclusion microthermometric data in Appendices $\mathrm{C}$ and D, radiometric $\mathrm{Rb}-\mathrm{Sr}$ geochronological data in Appendix E, stable isotope data in Appendix F, feldspar thermometric calculations in Appendix G, and mineral Ce and Eu anomalies in Appendix H. (Supplementary Materials)

\section{References}

[1] K. M. Goodenough, F. Wall, and D. Merriman, "The rare earth elements: demand, global resources, and challenges for resourcing future generations," Natural Resources Research, vol. 27, no. 2, pp. 201-216, 2018.

[2] S. Salvi and A. E. Williams-Jones, "Alteration, HFSE mineralisation and hydrocarbon formation in peralkaline igneous systems: insights from the Strange Lake Pluton, Canada," Lithos, vol. 91, no. 1-4, pp. 19-34, 2006.

[3] A. P. Gysi and A. E. Williams-Jones, "Hydrothermal mobilization of pegmatite-hosted REE and Zr at Strange Lake, Canada: a reaction path model," Geochimica et Cosmochimica Acta, vol. 122, pp. 324-352, 2013.

[4] S. Broom-Fendley, T. Heaton, F. Wall, and G. Gunn, "Tracing the fluid source of heavy REE mineralisation in carbonatites using a novel method of oxygen-isotope analysis in apatite: 
the example of Songwe Hill, Malawi," Chemical Geology, vol. 440, pp. 275-287, 2016.

[5] A. Migdisov, A. E. Williams-Jones, J. Brugger, and F. A. Caporuscio, "Hydrothermal transport, deposition, and fractionation of the REE: experimental data and thermodynamic calculations," Chemical Geology, vol. 439, pp. 13-42, 2016.

[6] O. V. Vasyukova, A. E. Williams-Jones, and N. J. F. Blamey, "Fluid evolution in the Strange Lake granitic pluton, Canada: implications for HFSE mobilisation," Chemical Geology, vol. 444, pp. 83-100, 2016.

[7] I. V. Veksler, A. M. Dorfman, M. Kamenetsky, P. Dulski, and D. B. Dingwell, "Partitioning of lanthanides and Y between immiscible silicate and fluoride melts, fluorite and cryolite and the origin of the lanthanide tetrad effect in igneous rocks," Geochimica et Cosmochimica Acta, vol. 69, no. 11, pp. 2847-2860, 2005.

[8] E. R. Sheard, A. E. Williams-Jones, M. Heiligmann, C. Pederson, and D. L. Trueman, "Controls on the concentration of zirconium, niobium, and the rare earth elements in the Thor Lake rare metal deposit, Northwest Territories, Canada," Economic Geology, vol. 107, no. 1, pp. 81-104, 2012.

[9] A. E. Williams-Jones, A. A. Migdisov, and I. M. Samson, "Hydrothermal mobilisation of the rare earth elements - a tale of "Ceria" and "Yttria"," Elements, vol. 8, no. 5, pp. 355-360, 2012.

[10] D. Debruyne, N. Hulsbosch, and P. Muchez, "Unraveling rare earth element signatures in hydrothermal carbonate minerals using a source-sink system," Ore Geology Reviews, vol. 72, pp. 232-252, 2016.

[11] A. A. Migdisov and A. E. Williams-Jones, "Hydrothermal transport and deposition of the rare earth elements by fluorine-bearing aqueous liquids," Mineralium Deposita, vol. 49, no. 8, pp. 987-997, 2014.

[12] E. P. Perry and A. P. Gysi, "Rare earth elements in mineral deposits: speciation in hydrothermal fluids and partitioning in calcite," Geofluids, vol. 2018, Article ID 5382480, 19 pages, 2018.

[13] O. V. Vasyukova and A. E. Williams-Jones, "Direct measurement of metal concentrations in fluid inclusions, a tale of hydrothermal alteration and REE ore formation from Strange Lake, Canada," Chemical Geology, vol. 483, pp. 385-396, 2018.

[14] M. P. Smith, P. Henderson, and L. S. Campbell, "Fractionation of the REE during hydrothermal processes: constraints from the Bayan Obo Fe-REE-Nb deposit, Inner Mongolia, China," Geochimica et Cosmochimica Acta, vol. 64, no. 18, pp. 3141-3160, 2000.

[15] S. Broom-Fendley, A. E. Brady, F. Wall, G. Gunn, and W. Dawes, "REE minerals at the Songwe Hill carbonatite, Malawi: HREE-enrichment in late-stage apatite," Ore Geology Reviews, vol. 81, pp. 23-41, 2017.

[16] T. Zack and K. J. Hogmalm, "Laser ablation Rb/Sr dating by online chemical separation of $\mathrm{Rb}$ and $\mathrm{Sr}$ in an oxygen-filled reaction cell," Chemical Geology, vol. 437, pp. 120-133, 2016.

[17] K.-I. Åhäll and S. Å. Larson, "Growth-related 1.85-1.55 Ga magmatism in the Baltic Shield; a review addressing the tectonic characteristics of Svecofennian, TIB 1-related, and Gothian events," GFF, vol. 122, no. 2, pp. 193-206, 2000.

[18] L. Brander and U. Söderlund, "Mesoproterozoic (1.47-1.44 Ga) orogenic magmatism in Fennoscandia; baddeleyite U-Pb dating of a suite of massif-type anorthosite in S. Sweden,"
International Journal of Earth Sciences, vol. 98, no. 3, pp. 499-516, 2009.

[19] S. V. Bogdanova, L. M. Page, G. Skridlaite, and L. N. Taran, "Proterozoic tectonothermal history in the western part of the East European Craton: ${ }^{40} \mathrm{Ar} /{ }^{39} \mathrm{Ar}$ geochronological constraints," Tectonophysics, vol. 339, no. 1-2, pp. 39-66, 2001.

[20] A. S. L. Sjöqvist and M. Tillberg, "Age and source of the Mesoproterozoic Götemar granite, southeast Sweden: crustal source of an anorogenic A-type granite," In preparation.

[21] A. R. Cruden, Emplacement mechanisms and structural influences of a younger granite intrusion into older wall rocks-a principal study with application to the Götemar and Uthammar granites. SKB Report R-08-138, SKB, Stockholm, 2008.

[22] N. Friese, A. Vollbrecht, D. C. Tanner, W. Fahlbusch, and M. Weidemann, "Multi-stage emplacement of the Götemar Pluton, SE Sweden: new evidence inferred from field observations and microfabric analysis, including cathodoluminescence microscopy," International Journal of Earth Sciences, vol. 101, no. 5, pp. 1149-1167, 2012.

[23] K.-A. Kornfält, P.-O. Persson, and H. Wikman, “Granitoids from the Äspö area, southeastern Sweden-geochemical and geochronological data," GFF, vol. 119, no. 2, pp. 109-114, 1997.

[24] P. Kresten and J. Chyssler, "The Götemar massif in southeastern Sweden: a reconnaissance survey," Geologiska Föreningen i Stockholm Förhandlingar, vol. 98, no. 2, pp. 155-161, 1976.

[25] J. A. T. Smellie and J. S. Stuckless, "Element mobility studies of two drill-cores from the Götemar granite (Kråkemåla test site), Southeast Sweden," Chemical Geology, vol. 51, no. 1-2, pp. 55-78, 1985.

[26] H. Drake and E.-L. Tullborg, "Paleohydrogeological events recorded by stable isotopes, fluid inclusions and trace elements in fracture minerals in crystalline rock, Simpevarp area, SE Sweden," Applied Geochemistry, vol. 24, no. 4, pp. 715-732, 2009.

[27] H. Drake, E.-L. Tullborg, and L. Page, "Distinguished multiple events of fracture mineralisation related to far-field orogenic effects in Paleoproterozoic crystalline rocks, Simpevarp area, SE Sweden," Lithos, vol. 110, no. 1-4, pp. 37-49, 2009.

[28] H. Drake, M. E. Åström, C. Heim et al., "Extreme ${ }^{13} \mathrm{C}$ depletion of carbonates formed during oxidation of biogenic methane in fractured granite," Nature Communications, vol. 6, no. 1, article 7020, 2015.

[29] H. Drake, C. Heim, N. M. W. Roberts et al., "Isotopic evidence for microbial production and consumption of methane in the upper continental crust throughout the Phanerozoic eon," Earth and Planetary Science Letters, vol. 470, pp. 108-118, 2017.

[30] H. Drake, E.-L. Tullborg, and H. Annersten, "Red-staining of the wall rock and its influence on the reducing capacity around water conducting fractures," Applied Geochemistry, vol. 23, no. 7, pp. 1898-1920, 2008.

[31] H. Drake, M. J. Whitehouse, C. Heim et al., "Unprecedented ${ }^{34}$ S-enrichment of pyrite formed following microbial sulfate reduction in fractured crystalline rocks," Geobiology, vol. 16, no. 5, pp. 556-574, 2018.

[32] C.-H. Wahlgren, P. Curtis, J. Hermanson et al., SKB Report R-08-54, SKB, Stockholm, 2008.

[33] J. M. McCrea, "On the isotopic chemistry of carbonates and a paleotemperature scale," The Journal of Chemical Physics, vol. 18 , no. 6 , pp. 849-857, 1950. 
[34] I. Friedman and J. R. O’Neil, “Data of geochemistry: compilation of stable isotope fractionation factors of geochemical interest, U.S. Geological Survey Professional Paper 440-KK," p. 11, 1977.

[35] B. W. Robinson and M. Kusakabe, "Quantitative preparation of sulfur dioxide, for sulfur-34/sulfur-32 analyses, from sulfides by combustion with cuprous oxide," Analytical Chemistry, vol. 47, no. 7, pp. 1179-1181, 2002.

[36] K. J. Hogmalm, T. Zack, A. K. O. Karlsson, A. S. L. Sjöqvist, and D. Garbe-Schönberg, "In situ Rb-Sr and K-Ca dating by LA-ICP-MS/MS: an evaluation of $\mathrm{N}_{2} \mathrm{O}$ and $\mathrm{SF}_{6}$ as reaction gases," Journal of Analytical Atomic Spectrometry, vol. 32, no. 2, pp. 305-313, 2017.

[37] K. Govindaraju, "Report (1968-1978) on two mica reference samples: biotite mica-Fe and phlogopite mica-Mg," Geostandards Newsletter, vol. 3, no. 1, pp. 3-24, 1979.

[38] E. Alm, K. Sundblad, and H. Huhma, "Sm-Nd isotope determinations of low-temperature fluorite-calcite-galena mineralization in the margins of the Fennoscandian Shield," SKB Report R-05-66, SKB, Stockholm, 2005.

[39] H. Wikman, K. A. Kornfält, and H. Huhma, "Updating of a lithological model of the bedrock of the Äspö area," SKB Progress Report, 25-95-04, SKB, Stockholm, 1995.

[40] N. M. Evensen, P. J. Hamilton, and R. K. O'Nions, "Rare-earth abundances in chondritic meteorites," Geochimica et Cosmochimica Acta, vol. 42, no. 8, pp. 1199-1212, 1978.

[41] R. J. Bodnar, "Introduction to aqueous fluid systems," in Fluid Inclusions: Analysis and Interpretation, I. Samson, A. Anderson, and D. Marshall, Eds., pp. 81-99, Mineralogical Association Canada, 2003, Short Course 32.

[42] R. J. Bodnar, "Synthetic fluid inclusions: XII. The system $\mathrm{H}_{2} \mathrm{O}-\mathrm{NaCl}$. Experimental determination of the halite liquidus and isochores for a $40 \mathrm{wt} \% \mathrm{NaCl}$ solution," Geochimica et Cosmochimica Acta, vol. 58, no. 3, pp. 1053-1063, 1994.

[43] A. Fall, B. Tattitch, and R. J. Bodnar, "Combined microthermometric and Raman spectroscopic technique to determine the salinity of $\mathrm{H}_{2} \mathrm{O}-\mathrm{CO}_{2}-\mathrm{NaCl}$ fluid inclusions based on clathrate melting," Geochimica et Cosmochimica Acta, vol. 75, no. 4, pp. 951-964, 2011.

[44] R. J. Bakker, J. Dubessy, and M. Cathelineau, "Improvements in clathrate modelling: I. The $\mathrm{H}_{2} \mathrm{O}-\mathrm{CO}_{2}$ system with various salts," Geochimica et Cosmochimica Acta, vol. 60, no. 10, pp. 1657-1681, 1996.

[45] E. Roedder and R. J. Bodnar, "Geologic pressure determinations from fluid inclusion studies," Annual Review of Earth and Planetary Sciences, vol. 8, no. 1, pp. 263-301, 1980.

[46] B. Sandström and E.-L. Tullborg, "Episodic fluid migration in the Fennoscandian Shield recorded by stable isotopes, rare earth elements and fluid inclusions in fracture minerals at Forsmark, Sweden," Chemical Geology, vol. 266, no. 3-4, pp. 126-142, 2009.

[47] K.-I. Åhäll, Åldersbestämning av svårdaterade bergarter $i$ sydöstra Sverige. SKB Report R-01-60, SKB, Stockholm, 2001.

[48] L. Monnier, P. Lach, S. Salvi et al., "Quartz trace-element composition by LA-ICP-MS as proxy for granite differentiation, hydrothermal episodes, and related mineralization: the Beauvoir granite (Echassières district), France," Lithos, vol. 320-321, pp. 355-377, 2018.

[49] W. E. Halter, A. E. Williams-Jones, and D. J. Kontak, “Origin and evolution of the greisenizing fluid at the East Kemptville tin deposit, Nova Scotia, Canada," Economic Geology, vol. 93, no. 7, pp. 1026-1051, 1998.
[50] C. Canet, S. I. Franco, R. M. Prol-Ledesma, E. GonzálezPartida, and R. E. Villanueva-Estrada, "A model of boiling for fluid inclusion studies: application to the Bolaños Ag-Au-Pb-Zn epithermal deposit, Western Mexico," Journal of Geochemical Exploration, vol. 110, no. 2, pp. 118-125, 2011.

[51] M. A. Cruz-Pérez, C. Canet, S. I. Franco, A. Camprubí, E. González-Partida, and A. Rajabi, "Boiling and depth calculations in active and fossil hydrothermal systems: a comparative approach based on fluid inclusion case studies from Mexico," Ore Geology Reviews, vol. 72, pp. 603-611, 2016.

[52] J. M. Ferry and E. B. Watson, "New thermodynamic models and revised calibrations for the Ti-in-zircon and $\mathrm{Zr}$-in-rutile thermometers," Contributions to Mineralogy and Petrology, vol. 154, no. 4, pp. 429-437, 2007.

[53] B. Fu, F. Z. Page, A. J. Cavosie et al., "Ti-in-zircon thermometry: applications and limitations," Contributions to Mineralogy and Petrology, vol. 156, no. 2, pp. 197-215, 2008.

[54] A. E. P. Douce, "Generation of metaluminous A-type granites by low-pressure melting of calc-alkaline granitoids," Geology, vol. 25, no. 8, pp. 743-746, 1997.

[55] K. D. Putirka, "Thermometers and barometers for volcanic systems," Reviews in Mineralogy and Geochemistry, vol. 69, no. 1, pp. 61-120, 2008.

[56] F. Pirajno, "Effects of metasomatism on mineral systems and their host rocks: alkali metasomatism, skarns, greisens, tourmalinites, rodingites, black-wall alteration and listvenites," in Metasomatism and the Chemical Transformation of Rock: The Role of Fluids in Terrestrial and Extraterrestrial Processes, D. E. Harlov and H. Austrheim, Eds., pp. 203-251, Springer Berlin Heidelberg, Berlin, Heidelberg, 2013.

[57] R. Sallet, R. Moritz, and D. Fontignie, "Fluorite ${ }^{87} \mathrm{Sr} /{ }^{86} \mathrm{Sr}$ and REE constraints on fluid-melt relations, crystallization time span and bulk $D^{\text {Sr }}$ of evolved high-silica granites. Tabuleiro granites, Santa Catarina, Brazil," Chemical Geology, vol. 164, no. 1-2, pp. 81-92, 2000.

[58] D. K. Bird and A. R. Spieler, "Epidote in geothermal systems," Reviews in Mineralogy and Geochemistry, vol. 56, no. 1, pp. 235-300, 2004.

[59] D. Frei, A. Liebscher, G. Franz, and P. Dulski, "Trace element geochemistry of epidote minerals," Reviews in Mineralogy and Geochemistry, vol. 56, no. 1, pp. 553-605, 2004.

[60] R. A. Mayanovic, A. J. Anderson, W. A. Bassett, and I.-M. Chou, "The structure and stability of aqueous rare-earth elements in hydrothermal fluids: new results on neodymiu$\mathrm{m}(\mathrm{III})$ aqua and chloroaqua complexes in aqueous solutions to $500^{\circ} \mathrm{C}$ and $520 \mathrm{MPa}$," Chemical Geology, vol. 259, no. 1-2, pp. 30-38, 2009.

[61] M. Bau and P. Dulski, "Comparative study of yttrium and rareearth element behaviours in fluorine-rich hydrothermal fluids," Contributions to Mineralogy and Petrology, vol. 119, no. 2-3, pp. 213-223, 1995.

[62] M. Bau, "Controls on the fractionation of isovalent trace elements in magmatic and aqueous systems: evidence from $\mathrm{Y} / \mathrm{Ho}, \mathrm{Zr} / \mathrm{Hf}$, and lanthanide tetrad effect," Contributions to Mineralogy and Petrology, vol. 123, no. 3, pp. 323-333, 1996.

[63] A. Loges, A. A. Migdisov, T. Wagner, A. E. Williams-Jones, and G. Markl, "An experimental study of the aqueous solubility and speciation of $\mathrm{Y}$ (III) fluoride at temperatures up to $250^{\circ} \mathrm{C}$," Geochimica et Cosmochimica Acta, vol. 123, pp. 403-415, 2013. 
[64] S. Ezaki, R. Hypolito, and A. Pérez-Aguilar, "Experimental fluorine liberation from Precambrian granites and Carboniferous-Permian sedimentary rocks associated with crystalline and sedimentary aquifers, Paraná Basin, southeastern Brazil," Geochemical Journal, vol. 50, no. 5, pp. 379-392, 2016.

[65] A. A. Migdisov, A. E. Williams-Jones, and T. Wagner, "An experimental study of the solubility and speciation of the rare earth elements (III) in fluoride- and chloride-bearing aqueous solutions at temperatures up to $300^{\circ} \mathrm{C}$," Geochimica et Cosmochimica Acta, vol. 73, no. 23, pp. 7087-7109, 2009.

[66] A. Tsay, Z. Zajacz, and C. Sanchez-Valle, "Efficient mobilization and fractionation of rare-earth elements by aqueous fluids upon slab dehydration," Earth and Planetary Science Letters, vol. 398, pp. 101-112, 2014.

[67] Y.-R. Luo and R. H. Byrne, "Carbonate complexation of yttrium and the rare earth elements in natural waters," Geochimica et Cosmochimica Acta, vol. 68, no. 4, pp. 691-699, 2004.

[68] J. L. Bischoff and R. J. Rosenbauer, "The alteration of rhyolite in $\mathrm{CO}_{2}$ charged water at 200 and $350^{\circ} \mathrm{C}$ : the unreactivity of $\mathrm{CO}_{2}$ at higher temperature," Geochimica et Cosmochimica Acta, vol. 60, no. 20, pp. 3859-3867, 1996.

[69] J.-T. Peng, R.-Z. Hu, and P. G. Burnard, "Samariumneodymium isotope systematics of hydrothermal calcites from the Xikuangshan antimony deposit (Hunan, China): the potential of calcite as a geochronometer," Chemical Geology, vol. 200, no. 1-2, pp. 129-136, 2003.

[70] J. Wang, H. Wen, H. Fan, and J. Zhu, "Sm-Nd geochronology, REE geochemistry and $\mathrm{C}$ and $\mathrm{O}$ isotope characteristics of calcites and stibnites from the Banian antimony deposit, Guizhou Province, China," Geochemical Journal, vol. 46, no. 5, pp. 393407, 2012. 

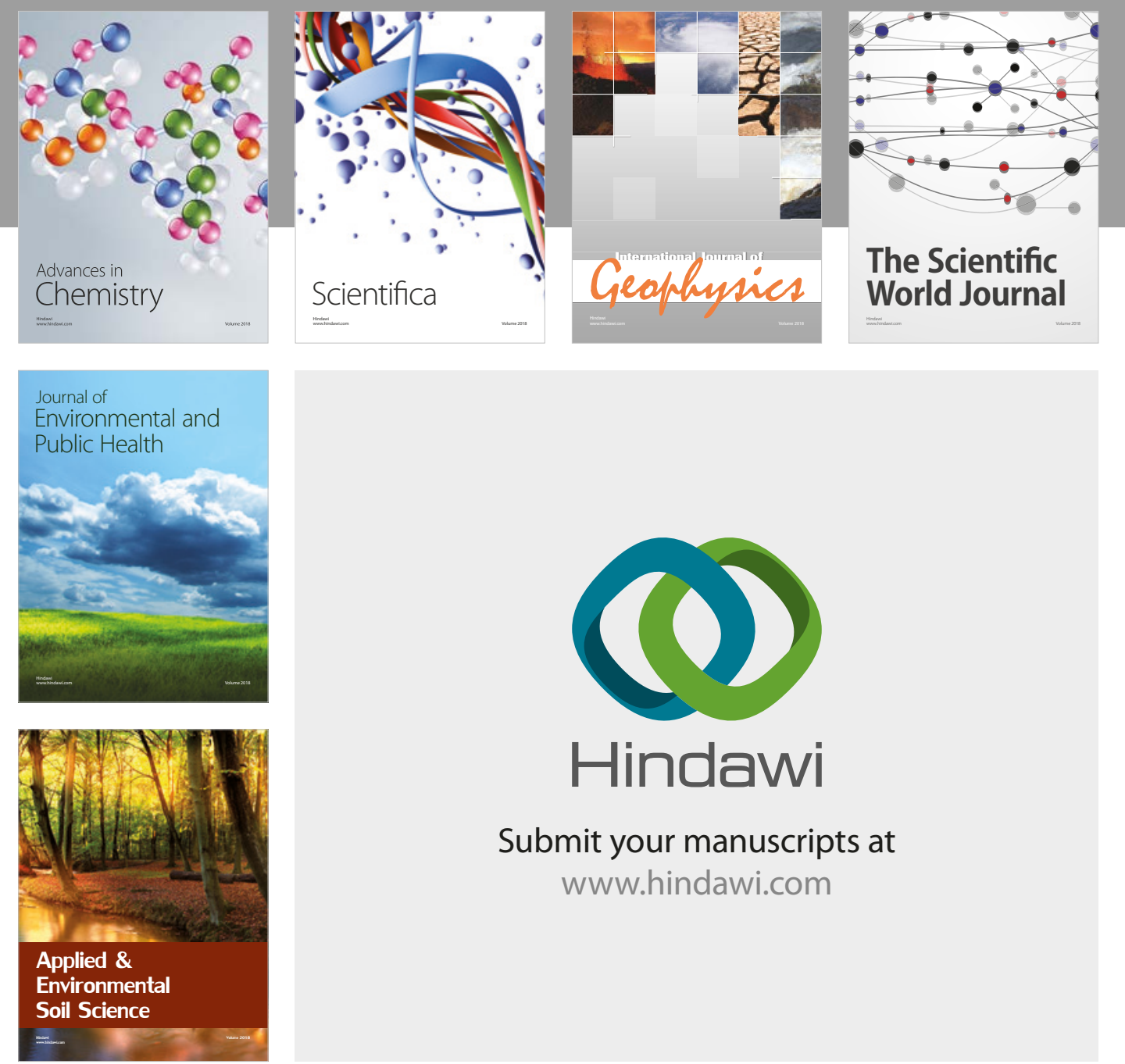

The Scientific

\section{World Journal}
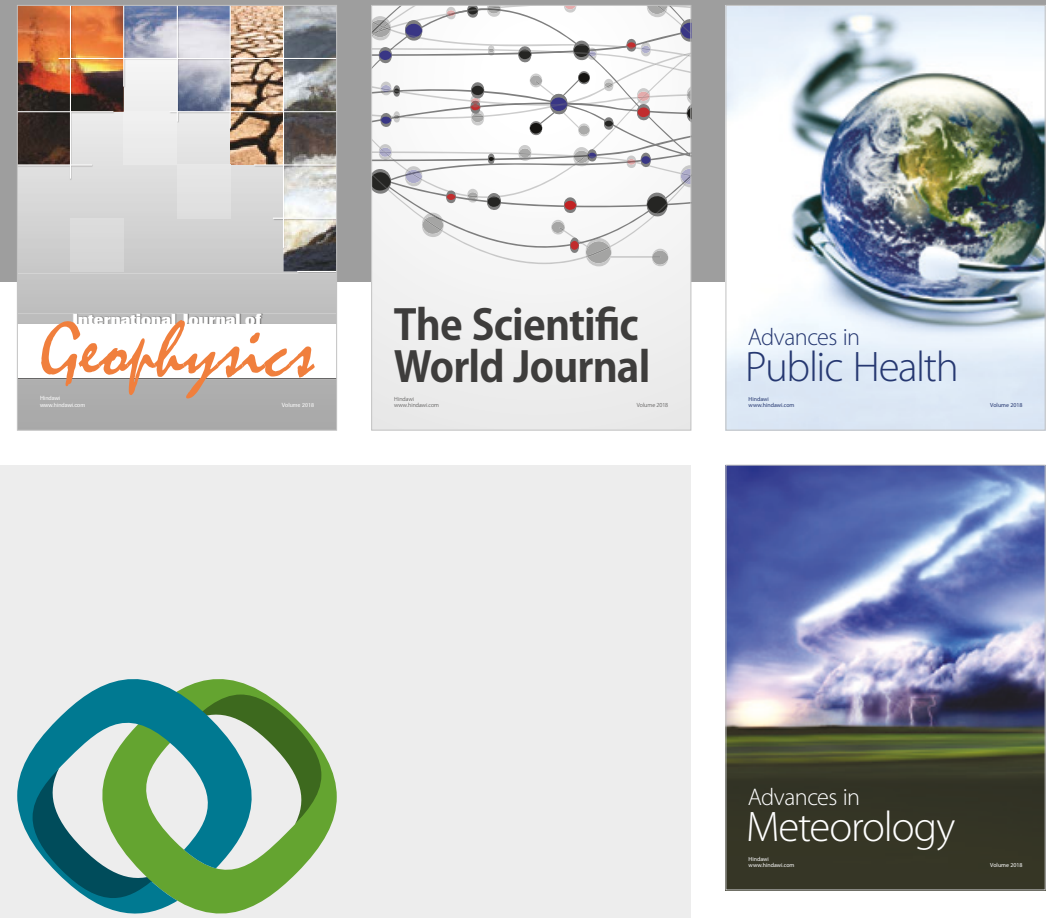

Advan

Public Health

\section{Hindawi}

Submit your manuscripts at

www.hindawi.com
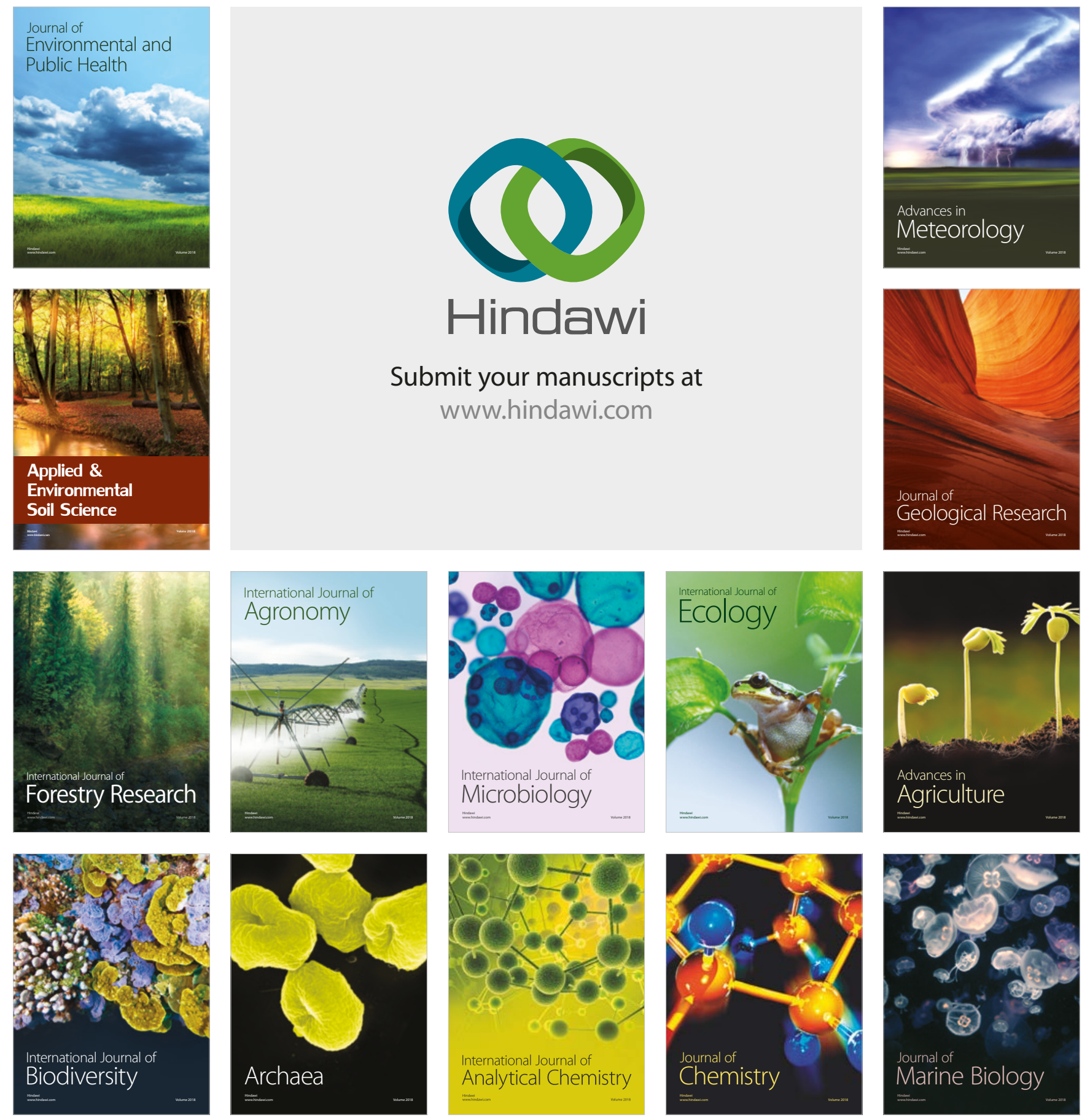